Article

\title{
Composition and Ligand Microstructure of Arsenopyrite from Gold Ore Deposits of the Yenisei Ridge (Eastern Siberia, Russia)
}

\author{
Anatoly M. Sazonov ${ }^{1, *}$, Sergey A. Silyanov ${ }^{1}$, Oleg A. Bayukov ${ }^{2}$, Yuriy V. Knyazev ${ }^{2}{ }^{(D}$, \\ Yelena A. Zvyagina ${ }^{1}$ and Platon A. Tishin ${ }^{3}$ \\ 1 Institute of Mining, Geology and Geotechnology, Siberian Federal University, 79 pr. Svobodny, \\ 660041 Krasnoyarsk, Russia; silyanov-s@mail.ru (S.A.S.); elena_zv@mail.ru (Y.A.Z.) \\ 2 Kirensky Institute of Physics, Federal Research Center Krasnoyarsk Scientific Center of the Siberian Branch \\ of the Russian Academy of Sciences, 50 Bld. 38 Akademgorodok, 660036 Krasnoyarsk, Russia; \\ helg@iph.krasn.ru (O.A.B.); yuvknyazev@mail.ru (Y.V.K.) \\ 3 Faculty of Geology and Geography, Tomsk National Research State University, 36 Lenina, \\ 634050 Tomsk, Russia; tishin_pa@mail.ru \\ * Correspondence: sazonov_am@mail.ru; Tel.: +7-902-923-5177
}

Received: 13 October 2019; Accepted: 26 November 2019; Published: 28 November 2019

\begin{abstract}
The Mössbauer spectroscopy method was used to study the ligand microstructure of natural arsenopyrite (31 specimens) from the ores of the major gold deposits of the Yenisei Ridge (Eastern Siberia, Russia). Arsenopyrite and native gold are paragenetic minerals in the ore; meanwhile, arsenopyrite is frequently a gold carrier. We detected iron positions with variable distribution of sulfur and arsenic anions at the vertexes of the coordination octahedron $\{6 \mathrm{~S}\},\{5 \mathrm{~S} 1 \mathrm{As}\},\{4 \mathrm{~S} 2 \mathrm{As}\}$, $\{3 \mathrm{~S} 3 \mathrm{As}\},\{2 \mathrm{~S} 4 \mathrm{As}\},\{1 \mathrm{~S} 5 \mathrm{As}\},\{6 \mathrm{As}\}$ in the mineral structure. Iron atoms with reduced local symmetry in tetrahedral cavities, as well as iron in the high-spin condition with a high local symmetry of the first coordination sphere, were identified. The configuration \{3S3As\} typical for the stoichiometric arsenopyrite is the most occupied. The occupation degree of other configurations is not subordinated to the statistic distribution and varies within a wide range. The presence of configurations $\{6 \mathrm{~S}\}$, $\{3 \mathrm{~S} 3 \mathrm{As}\},\{6 \mathrm{As}\}$ and their variable occupation degree indicate that natural arsenopyrites are solid pyrite $\{6 \mathrm{~S}\}$, arsenopyrite $\{3 \mathrm{~S} 3 \mathrm{As}\}$, and loellingite $\{6 \mathrm{As}\}$ solutions, with the thermodynamic preference to the formation of configurations in the arsenopyrite-pyrite-loellingite order. It is assumed that in the variations as part of the coordination octahedron, the iron output to the tetrahedral positions and the presence of high-spin Fe cations depend on the physical and chemical conditions of the mineral formation. It was identified that the increased gold concentrations are typical for arsenopyrites with an elevated content of sulfur or arsenic and correlate with the increase of the occupation degree of configurations $\{5 \mathrm{~S} 1 \mathrm{As}\},\{4 \mathrm{~S} 2 \mathrm{As}\},\{1 \mathrm{~S} 5 \mathrm{As}\}$, reduction of the share of $\{3 \mathrm{~S} 3 \mathrm{As}\}$, and the amount of iron in tetrahedral cavities.
\end{abstract}

Keywords: arsenopyrite; crystal lattice; ligand surroundings; non-equal positions; Mössbauer Effect; gold; "invisible" gold; gold ore deposits

\section{Introduction}

Arsenopyrite is a quasistoichometric mineral with the chemical formula FeAsS. The chemical composition of the mineral is sensitive to the physical and chemical conditions of formation and is used for studying the thermodynamic parameters of hydrothermal ore formation [1-6]. In most gold ore deposits, arsenopyrite is present in significant quantities. The interrelation of the $\mathrm{S} /$ As ratio with the gold content in arsenopyrite ores has been noted; however, unambiguous dependence has not 
been demonstrated [6-10]. It is assumed that gold in arsenopyrite can be present in a metal and/or chemically bound states [11-22].

The crystal structure of stoichiometric arsenopyrite (FeAsS) demonstrates that the mineral is of monoclinic symmetry (space group $P 21 / c$ ); the parameters of the elementary cell have been identified as $a=5.7612(8), b=5.6841(7), c=5.7674(8) \AA, \beta=111.72^{\circ}$ [23-25]. Iron in the crystal lattice of arsenopyrite is located in the center of distorted octahedrons formed by sulfur and arsenic atoms. Meanwhile, the $S$ and As atoms occupy the vertexes of the opposite planes of the octahedron [26,27].

Moreover, the Mössbauer spectroscopy of natural arsenopyrites [4,26] shows three quadrupole doublets, the chemical shift (IS $=0.34 \mathrm{~mm} / \mathrm{s}$ ), and quadrupole splitting (QS $=1.05 \mathrm{~mm} / \mathrm{s}$ ) of which is close to the parameters of pyrite- $-\mathrm{FeS}_{2}$ (IS $=0.314 \mathrm{~mm} / \mathrm{s}, \quad Q S=0.614 \mathrm{~mm} / \mathrm{s}$ ); marcasite- $\mathrm{FeS}_{2}$ (IS = $\left.0.27 \mathrm{~mm} / \mathrm{s}, \mathrm{QS}=0.50 \mathrm{~mm} / \mathrm{s}\right)$; arsenopyrite-FeAsS (IS = $0.34 \mathrm{~mm} / \mathrm{s}, \mathrm{QS}=1.05 \mathrm{~mm} / \mathrm{s}$ ); loellingite- $\mathrm{FeAs}_{2}$ (IS $\left.=0.39 \mathrm{~mm} / \mathrm{s}, \mathrm{QS}=1.68 \mathrm{~mm} / \mathrm{s}\right)$ [28,29]. Iron in these structural motives is in the low-spin condition [26,30,31]. Some arsenopyrite specimens contain additional iron positions explained by the occurrence of high-spin cations of $\mathrm{Fe}^{2+}$ and the formation of the nearest ligand surroundings $(2 \mathrm{~S}+4 \mathrm{As})$. Recently, an attempt was made to explain the occurrence of non-equivalent iron positions in arsenopyrites with different sulfur and arsenic distribution by vertexes of the coordination octahedron [6,25]. Natural arsenopyrite is heterogeneous in terms of the sulfur and arsenic content, which can be observed even within a single crystal grain $[6,9,13]$. This agrees with the variations of the ligand surroundings of iron and can cause the occurrence of gold in the arsenopyrite structure $[6,9]$.

Arsenopyrite is characterized by a wide range of chemical compositions and variations in the crystalline structure, which explains presence of "invisible" gold in it. Despite a large number of publications dedicated to the arsenopyrite structure, such studies have been performed for a limited number of specimens. In this paper, the results of studies of the chemical and structural heterogeneity of arsenopyrite associated with gold and as one of the main carriers of gold are given. The representative selection of the samples consisting of 31 arsenopyrite specimens from the ores of 13 gold deposits of the Yenisei Ridge (Siberia, Russia) was studied.

\section{General Data on Geology of Gold-Arsenopyrite Mineralization of the Yenisei Ridge}

The Yenisei Ridge, as a unique geological province in terms of gold reserves, is located in Eastern Siberia (Russia) and is confined to the junction of the West Siberian Plateau and the Siberian Platform (Figure 1). Two geological-structural elements, Anagara-Kan Archaean and Lower Proterozoic offset (interfluve of the Kan and Angara Rivers) and the Zaangarskoye folding structure of the Baikal age (from the lower reaches of the Angara River to the estuary of the Podkamennaya Tunguska River), form the structure of the Yenisei Ridge. The boundary between the structural elements of the ridge coincide with the valley of the Angara River, which is confined to the broadly West-East fault zone. The multiple gold ore units are grouped in the eastern part of the structure of the ridge in the form of an extended $(350 \mathrm{~km})$ belt called the Eastern gold-bearing belt of the Yenisei Ridge. 


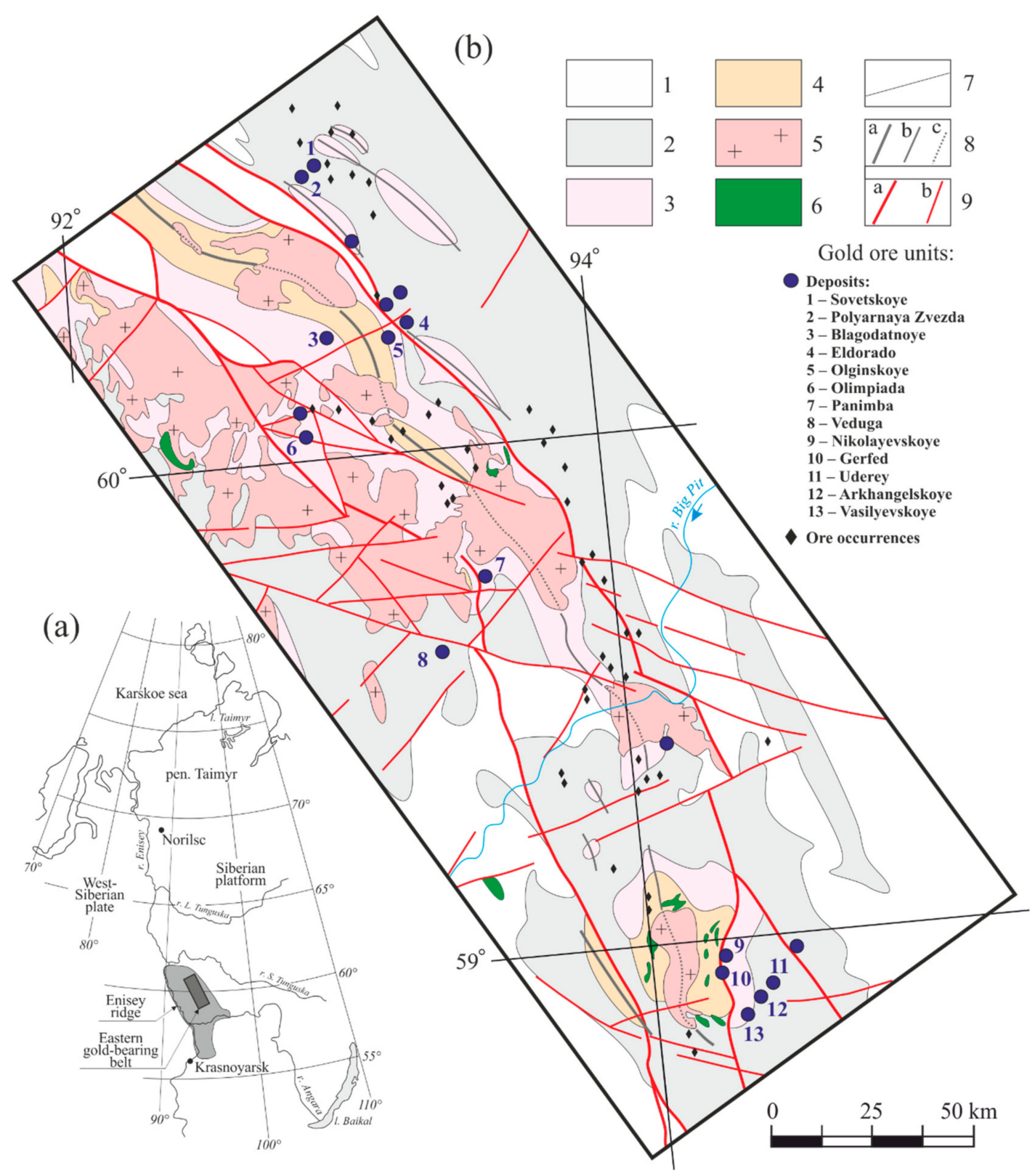

Figure 1. (a) Geographic position of the Yenisei Ridge (gray) and Eastern gold-bearing belt (dark gray); (b) map of geological structure of the Eastern gold-bearing belt of the Yenisei Ridge (compiled by A.M. Sazonov): 1—stratified Upper Riphean-Cambrian deposits; 2-Middle Riphean. Aladyinskaya, Pogoryuy, Uderey, and Gorbilok suites (dolomites, clay slates, siltstone, sandstone, carboniferous phyllites, chlorite-micaceous slates, and phyllites); 3-Lower Riphean. Kordinskaya suite-quartzite-like two-mica slates, gravelites, limestones; 4-Lower Proterozoic. Penchenginskaya suite and suite of the Karpinsky Ridge (quartzites, amphibolites, aluminous slates, and gneiss); 5-Proterozoic granitoid; 6-Proterozoic intrusions of mafic composition; 7-geological borders; 8-anticline axes of: $\mathrm{a}$-Teya series; $\mathrm{b}$-Kordinskaya suite; $\mathrm{c}$ - anticline axes within granite intrusions; 9-faults: a-major, $b$-other.

The gold ore deposits are located in the metamorphosed deposits of the Sukhopitskaya Riphean series. The thickness of the stratified layers in the region was $17.25 \mathrm{~km}$ at the final stages of ore formation (approximately $600 \mathrm{Ma}$ ). The vertical span of mineralization distribution is about $3.25 \mathrm{~km}$ in the lower part of the section of Vendian-Riphean deposits. The lithostatic pressure in this interval of the ore-hosting stratum was $3.6 \mathrm{kbar}$ in the upper part of the ore shoot and $4.4 \mathrm{kbar}$ in the lower part, and the 
temperature was 450 and $560^{\circ} \mathrm{C}$, respectively, at a gradient of $33^{\circ} / \mathrm{km}$ [32]. The host rocks of the deposits are represented by meta-aleuropelites, less often carbonate rocks and metasandstones metamorphosed in the conditions of the greenschist up to epidote-amphibolite facies. Granite intrusions, which the genesis of the deposits is associated with, are located at a distance of 1.5 to $18 \mathrm{~km}$. The wide range of distribution of deposits in relation to the granitoid massifs and a significant distance of some deposits from granites defines the negotiable nature of the genetic relationship between granitoid magmatism and mineralization. The deposits are classified as a gold-quartz-sulfide type. The ore bodies are represented by quartz veins with variable thickness, with sulfide mineralization and zones of sulfidized, silicified, and sericite-altered schists. The ore bodies have been formed in various temporal stages: quartz-vein (I), gold-arsenopyrite (II), sulfide-polymetal (III), ulmanite-gersdorffite (IV), and stibnite (V) [33-37]. The main volume of gold in the ores was formed in connection with the occurrence of the arsenopyrite stage. In the later stages of the hydrothermal process, as a result of metamorphism of early formations and telescoping of ore deposition, arsenopyrite, gold, and other early minerals of the ores were recrystallized and redeposited with consolidation or disintegration of particles. Functioning of the hydrothermal system, which led to the formation of gold ore deposits, is estimated to last about $150 \mathrm{Ma}[37,38]$.

\section{Preparations and Research Methods}

In this work, we studied the composition, ligand surroundings of iron, and features of microparticle and gold distribution in 31 arsenopyrite specimens from the ores of 13 gold deposits at the Yenisei Ridge.

Arsenopyrite was collected from ores of the Sovetskoye, Polyarnaya Zvezda, Blagodatnoye, Eldorado, Olginskoye, Olimpiada, Panimba, Veduga, Nikolayevskoye, Gerfed, Uderey, Arkhangelskoye, and Vasilyevskoye deposits (Figure 1). The features of geology, ore composition, and formation conditions have been discussed in the early works of the authors [37,39]. The ore samples containing arsenopyrite were exposed to soft crushing in the metal mortar up to the fraction size of -1 to $+0.5 \mathrm{~mm}$. This fraction further was processed with the water-gravity method. The selection of arsenopyrite grains was carried out manually under the binocular magnifier. Twenty mineral grains were selected and sealed into epoxy pellets (each) from the obtained arsenopyrite weighted portions for the electron microscopic study and determination of the $\mathrm{Fe}, \mathrm{As}$, and $\mathrm{S}$. The remaining part of the weighted portions was ground in the agate mortar for the Mössbauer study, as well as for determination of concentrations of gold and other impurities with the ICP-MS method.

Monomineral arsenopyrite powders with a particle size of no more than 10 microns were used for the Mössbauer study. The purity of the samples analyzed was controlled by a parallel X-ray analysis, which did not demonstrate the presence of other mineral phases (e.g., pyrite, pyrrhotite, and lollingite) $[6,25]$. The thickness of the specimens was $5-10 \mathrm{mg} / \mathrm{cm}^{2}$. The Mössbauer spectra of arsenopyrites were measured at room temperature in the MC-1104Emspectrometer in the transmission geometry with the Mössbauer source of $\mathrm{Co}^{57}(\mathrm{Cr})$, at the natural iron content. The analysis was performed at the Institute of Physics, Siberian Branch of the Russian Academy of Sciences, Krasnoyarsk.

Determination of the main mineral-forming elements ( $\mathrm{Fe}, \mathrm{As}, \mathrm{S}, \mathrm{Au}$ ) in the local areas of mineral grains was performed using a TESCAN VEGA II LMU scanning electron microscope with an integrated system of X-ray energy-dispersive microanalysis OXFORD INCA ENERGY 350. Minerals were analyzed at $20 \mathrm{kV}$ and $1.2 \mathrm{nA}$. Pure elements $\left(\mathrm{Au}, \mathrm{Ag}, \mathrm{Cu}\right.$ ), as well as $\mathrm{FeS}_{2}$ (for $\mathrm{S}$ and Fe) and InAs (for As), were used as standards.

Impurity elements $(\mathrm{Au}, \mathrm{Ag}, \mathrm{Ru}, \mathrm{Pd}, \mathrm{Pt})$ in arsenopyrite were determined with the ICP-MS method in the Agilent 7500cx device manufactured by Agilent Technologies. The sulfide sample weighted portion was preliminarily transferred by progressive digestion into nitric acid and aqua regia solutions, which allowed it to be kept in the liquid phase and for the maximum possible set of elements to be analyzed. The quality of the obtained results was estimated on the basis of rock and ore standards BCR-2, BHWO, SSL-1. The analyses to determine the main mineral-forming elements and impurities 
were performed in the common-use center "Analytical Center of Geochemistry of Natural Systems" of the Tomsk State University, Tomsk, Russia.

\section{Results and Discussion}

\subsection{Mössbauer Spectroscopy}

The Mössbauer arsenopyrite spectra represent quadrupole doublets with asymmetric absorption lines. This asymmetry indicates that the spectra can be the sum of several doublets (Figure 2a). The spectra were interpreted in two stages. First, the distribution of the probability of quadrupole splittings in the experimental spectrum was determined. This made it possible to determine probable non-equivalent crystallographic positions of iron. For this purpose, a model spectrum was formed, which is the sum of three groups of doublets with a natural line of absorption. These groups represented a set of quadrupole doublets with the quadrupole splitting (QS) values from 0.0 to $2.0 \mathrm{~mm} / \mathrm{s}$, with a space of $0.01 \mathrm{~mm} / \mathrm{s}$. Each group of doublets has a certain chemical shift (IS) (Figure 2b). Then, the isomer shift and intensity of Mössbauer lines were varied. As a result, we obtained a set of intensities corresponding to each group. These data conform to the probability of each doublet's existence in the experimental spectrum. The result of processing at the first stage was distributions of probability $\mathrm{P}(\mathrm{QS})$ for each group.

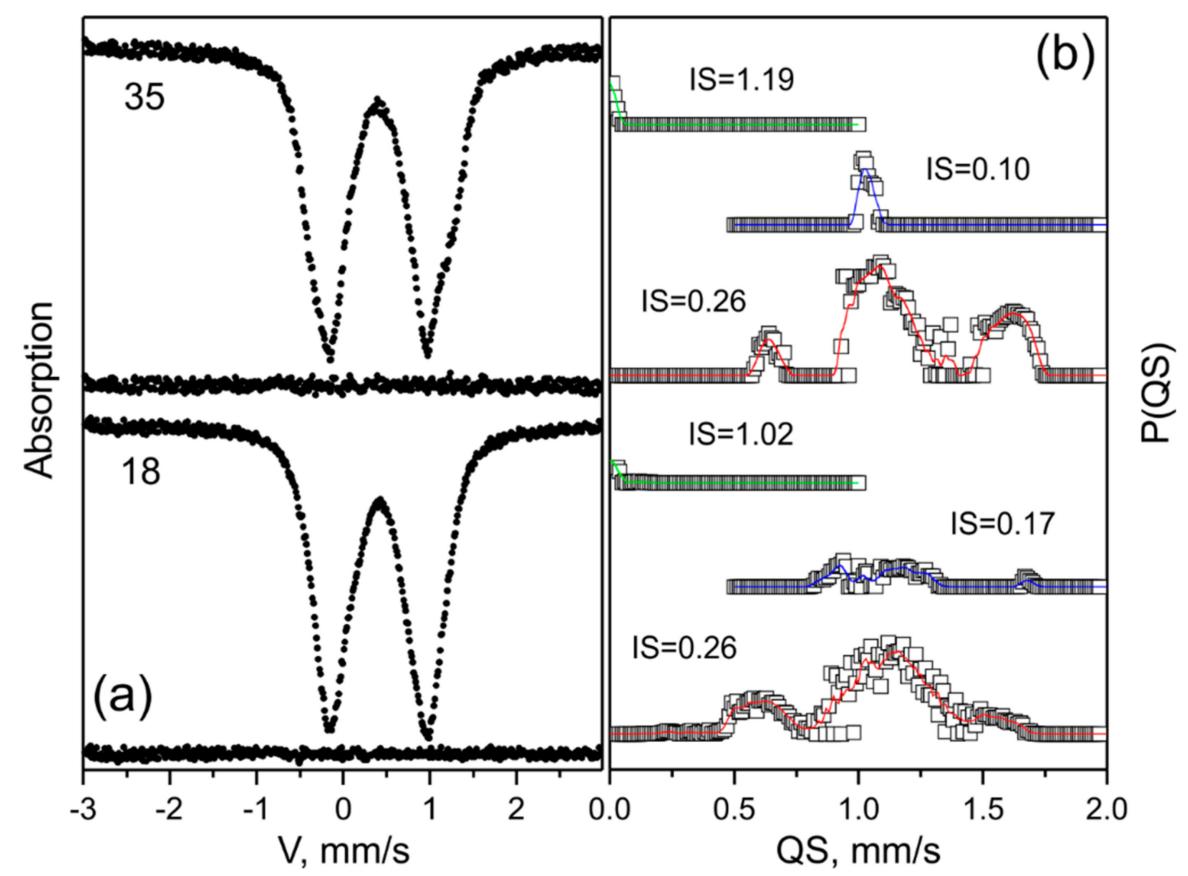

Figure 2. (a) Mössbauer spectra of arsenopyrites of the Sovetskoye deposit (18) and Blagodatnoye deposit (35), the difference between the theoretical and experimental spectra is shown under the spectra; (b) distribution of the probability of quadrupole splittings (QS) in the spectra of these specimens.

The solid lines show the approximation of the calculated data.

The peaks and features of the $\mathrm{P}(\mathrm{QS})$ distribution obtained are the occurrences of possible nonequivalent iron positions and/or states with different distortion of the local surroundings and electronic density. However, the occurrence of false peaks is possible.

The second stage of spectra interpretation was performed taking into account the detected peculiarities of the $\mathrm{P}(\mathrm{QS})$ distribution. A preliminary spectrum contained a set of Mössbauer doublets, 
corresponding to possible nonequivalent positions and modeling as a group of the analytical functions. Mössbauer absorption lines were represented by the pseudo-Voigt function, following the Equation

$$
I=I \frac{W^{2}}{W^{2}+4 \cdot(I S-i)^{2}}
$$

Here, $x_{i}=2 \cdot\left(\frac{I S-i}{W}\right), i$ is a channel number. $I, I S$, and $W$ are hyperfine parameters (line intensity, isomer shift, and line-width, respectively).

The model spectrum was fit to the experimental spectrum with variation of the whole set of hyperfine parameters. Meanwhile, in the course of spectra fitting, the amplitudes and widths of false doublets tended to zero, and the parameters of actual doublets were consolidated.

To reveal the nature of occurrence of non-equivalent iron positions in arsenopyrites, the preliminary evaluation of the main component of the electric field gradient (EFG) was performed in the pyrite-arsenopyrite-loellingite series with the use of the X-ray structural data on inter-ion distances $[27,40,41]$. The observed quadrupole splittings for pyrite, arsenopyrite, and loellingite "phases" marked in Figure 3 with crosses reflect the linear dependence.

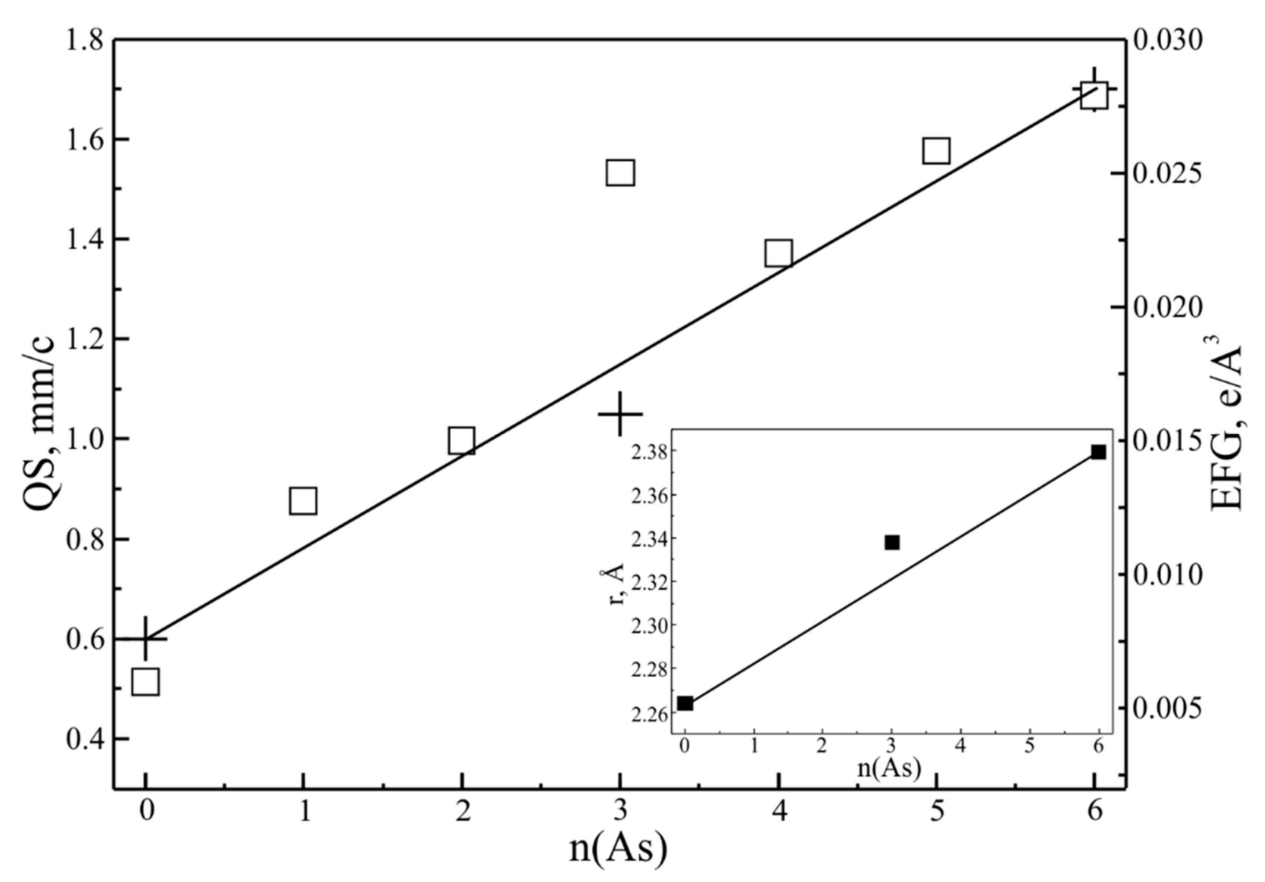

Figure 3. Dependence of quadrupole splitting (QS) and electric field gradient (EFG) on the number of arsenic atoms in the coordination ligand octahedron around the iron cation. Crosses are experimental QS values for pyrite, arsenopyrite, and loellingite [28,30]. $\mathrm{n}(\mathrm{As})$ is the number of As atoms in the coordination octahedron; $r, \AA$ is the average interionic distance.

The electronic envelope of the low-spin $\mathrm{Fe}^{2+}$ cation has spherical symmetry similar to the $\mathrm{S}$ ion; therefore, it is assumed that the EFG at the core of this cation is preconditioned mainly by the lattice contribution. The result of the EFG evaluation at the iron cation formed by ligands of the coordination octahedron at a different number of $S$ and As atoms in the octahedron is shown by squares (Figure 3). In the EFG evaluation, only the change of the Fe-S and Fe-As inter-ion distances at the replacement of $S$ with As was taken into account. The calculated EFG values repeat the linear dependence of quadrupole splitting (degree of octahedron deviation) on the ligand composition. The noticeable deviation of the EFG calculated value on the linear dependence for $n(A s)=3$ is probably associated with the features of the ligand ordering and change in the covalent contribution to EFG at the change of inter-ion distances for this composition. The dependence of the average inter-ion distance on $n(A s)$ is shown in the insert 
in Figure 3. The monotonic dependence of the quadrupole splitting on the As content in the nearest surroundings of the iron cation was used for the identification of ligand configurations.

According to the spot microprobe tests, the contents of sulfur and arsenic in the studied arsenopyrites varies. The $\mathrm{S} /$ As ratio varies from 0.79 to 1.24 both for different deposits and for grains in one sample. The estimated distribution of $\mathrm{P}(\mathrm{QS})$ using a single group of doublets with a general chemical shift is shown in Figure $2 b$ and demonstrates the main peak, the position of which corresponds to the quadrupole splitting of arsenopyrite. However, in addition to the main peak, there are also additional peaks; the quadrupole splittings of which are close to the parameters of pyrite $\mathrm{FeS}_{2}$ and loellingite $\mathrm{FeAs}_{2}$.

Processing of experimental spectra of the majority of the studied arsenopyrites using three doublets gives an unsatisfactory result, which testifies to the presence of additional unaccounted iron positions. The analysis of the spectrum - taking into account the three electronic iron conditions (three chemical shifts) - helped to reveal the additional nonequivalent iron positions both as a part of the main arsenopyrite phase leading to the smearing of the $\mathrm{P}(\mathrm{QS})$ distribution of main peaks, and the iron position with a minor and major value of chemical shifts not typical for arsenopyrites (Figure $2 b$ ). The result of the two-stage interpretation of the arsenopyrite spectra is given in Table 1.

Table 1. Mössbauer parameters of the studied specimens of arsenopyrite.

\begin{tabular}{|c|c|c|c|c|c|}
\hline $\begin{array}{l}\text { Specimen Number, Deposit, Morphology of } \\
\text { Arsenopyrite Grains (Mineralization Stage) }\end{array}$ & $\begin{array}{l}\text { IS, } \mathrm{mm} / \mathrm{s} \\
( \pm 0.005)\end{array}$ & $\begin{array}{c}\mathrm{QS}, \mathrm{mm} / \mathrm{s} \\
( \pm 0.02)\end{array}$ & $\begin{array}{l}\mathrm{W}, \mathrm{mm} / \mathrm{s} \\
( \pm 0.02)\end{array}$ & $\begin{array}{l}\text { A, \% } \\
( \pm 3)\end{array}$ & $\begin{array}{l}\text { Configuration } \\
\text { of Ligands }\end{array}$ \\
\hline \multirow{6}{*}{$\begin{array}{l}\text { 1. Olimpiada, isometric pseudopyramidal } \\
\text { grains (IV) }\end{array}$} & 0.26 & 0.58 & 0.33 & 8 & $\{6 \mathrm{~S}\}$ \\
\hline & 0.25 & 1.11 & 0.33 & 68 & $\{3 \mathrm{~S} 3 \mathrm{As}\}$ \\
\hline & 0.25 & 1.20 & 0.27 & 15 & $\{2 \mathrm{~S} 4 \mathrm{As}\}$ \\
\hline & 0.11 & 0.97 & 0.23 & 3 & Fe-LC-1 \\
\hline & 0.21 & 1.56 & 0.28 & 4 & Fe-LC-2 \\
\hline & 1.00 & 0.11 & 0.24 & 2 & Fe-HS \\
\hline \multirow{5}{*}{$\begin{array}{l}\text { 2. Olimpiada, isometric pseudopyramidal } \\
\text { grains (IV) }\end{array}$} & 0.29 & 0.58 & 0.28 & 8 & $\{6 \mathrm{~S}\}$ \\
\hline & 0.25 & 1.14 & 0.35 & 69 & $\{3 \mathrm{~S} 3 \mathrm{As}\}$ \\
\hline & 0.28 & 1.28 & 0.36 & 18 & $\{2 \mathrm{~S} 4 \mathrm{As}\}$ \\
\hline & 0.13 & 0.94 & 0.26 & 2 & Fe-LC-1 \\
\hline & 0.15 & 1.28 & 0.22 & 3 & Fe-LC-2 \\
\hline \multirow{5}{*}{ 3. Olimpiada, prismatic grains (IV) } & 0.26 & 0.64 & 0.36 & 13 & $\{6 \mathrm{~S}\}$ \\
\hline & 0.24 & 1.11 & 0.33 & 66 & $\{3 \mathrm{~S} 3 \mathrm{As}\}$ \\
\hline & 0.26 & 1.30 & 0.26 & 8 & $\{2 \mathrm{~S} 4 \mathrm{As}\}$ \\
\hline & 0.26 & 1.66 & 0.40 & 11 & $\{6 \mathrm{As}\}$ \\
\hline & 0.90 & 0.11 & 0.22 & 2 & Fe-HS \\
\hline \multirow{7}{*}{ 4. Olimpiada, needle-like grains (IV) } & 0.28 & 0.53 & 0.32 & 14 & $\{6 S\}$ \\
\hline & 0.25 & 0.75 & 0.24 & 6 & $\{5 \mathrm{~S} 1 \mathrm{As}\}$ \\
\hline & 0.25 & 1.10 & 0.35 & 65 & $\{3 \mathrm{~S} 3 \mathrm{As}\}$ \\
\hline & 0.26 & 1.27 & 0.23 & 5 & $\{2 \mathrm{~S} 4 \mathrm{As}\}$ \\
\hline & 0.24 & 1.58 & 0.24 & 3 & $\{6 \mathrm{As}\}$ \\
\hline & 0.15 & 1.14 & 0.28 & 5 & Fe-LC-1 \\
\hline & 1.00 & 0.14 & 0.22 & 2 & Fe-HS \\
\hline \multirow{6}{*}{ 5. Olimpiada, prismatic grains (III) } & 0.26 & 0.62 & 0.38 & 18 & $\{6 S\}$ \\
\hline & 0.26 & 1.10 & 0.29 & 54 & $\{3 \mathrm{~S} 3 \mathrm{As}\}$ \\
\hline & 0.25 & 1.22 & 0.26 & 11 & $\{2 \mathrm{~S} 4 \mathrm{As}\}$ \\
\hline & 0.24 & 1.55 & 0.29 & 7 & $\{6 \mathrm{As}\}$ \\
\hline & 0.16 & 1.04 & 0.29 & 9 & Fe-LC-1 \\
\hline & 0.92 & 0.15 & 0.28 & 2 & Fe-HS \\
\hline \multirow{7}{*}{$\begin{array}{l}\text { 6. Olimpiada, isometric pseudopyramidal } \\
\text { grains }(V)\end{array}$} & 0.25 & 0.58 & 0.33 & 10 & $\{6 S\}$ \\
\hline & 0.26 & 1.10 & 0.27 & 63 & $\{3 \mathrm{~S} 3 \mathrm{As}\}$ \\
\hline & 0.25 & 1.32 & 0.23 & 8 & $\{2 \mathrm{~S} 4 \mathrm{As}\}$ \\
\hline & 0.25 & 1.64 & 0.36 & 6 & $\{6 \mathrm{As}\}$ \\
\hline & 0.15 & 1.06 & 0.22 & 8 & Fe-LC-1 \\
\hline & 0.20 & 1.61 & 0.23 & 3 & Fe-LC-2 \\
\hline & 0.92 & 0.16 & 0.22 & 2 & Fe-HS \\
\hline
\end{tabular}


Table 1. Cont.

\begin{tabular}{|c|c|c|c|c|c|}
\hline $\begin{array}{l}\text { Specimen Number, Deposit, Morphology of } \\
\text { Arsenopyrite Grains (Mineralization Stage) }\end{array}$ & $\begin{array}{l}\text { IS, } \mathrm{mm} / \mathrm{s} \\
( \pm 0.005)\end{array}$ & $\begin{array}{l}\mathrm{QS}, \mathrm{mm} / \mathrm{s} \\
( \pm 0.02)\end{array}$ & $\begin{array}{c}\mathrm{W}, \mathrm{mm} / \mathrm{s} \\
( \pm 0.02)\end{array}$ & $\begin{array}{l}\text { A, \% } \\
( \pm 3)\end{array}$ & $\begin{array}{c}\text { Configuration } \\
\text { of Ligands }\end{array}$ \\
\hline \multirow{7}{*}{ 7. Olimpiada, prismatic grains (II) } & 0.27 & 0.61 & 0.32 & 8 & $\{6 S\}$ \\
\hline & 0.25 & 1.10 & 0.29 & 70 & $\{3 \mathrm{~S} 3 \mathrm{As}\}$ \\
\hline & 0.23 & 1.21 & 0.24 & 12 & $\{2 \mathrm{~S} 4 \mathrm{As}\}$ \\
\hline & 0.20 & 1.58 & 0.23 & 2 & $\{6 \mathrm{As}\}$ \\
\hline & 0.18 & 0.95 & 0.22 & 4 & Fe-LC-1 \\
\hline & 0.18 & 1.36 & 0.21 & 2 & Fe-LC-2 \\
\hline & 1.04 & 0.10 & 0.29 & 2 & Fe-HS \\
\hline \multirow{7}{*}{$\begin{array}{l}\text { 18. Sovetskoye, aggregates of coalescent } \\
\text { pseudopyramidal grains (III) }\end{array}$} & 0.31 & 0.60 & 0.31 & 12 & $\{6 S\}$ \\
\hline & 0.26 & 0.81 & 0.29 & 10 & $\{4 \mathrm{~S} 2 \mathrm{As}\}$ \\
\hline & 0.26 & 1.13 & 0.33 & 59 & $\{3 \mathrm{~S} 3 \mathrm{As}\}$ \\
\hline & 0.23 & 1.56 & 0.22 & 8 & $\{6 \mathrm{As}\}$ \\
\hline & 0.12 & 0.80 & 0.23 & 5 & Fe-LC-1 \\
\hline & 0.15 & 1.40 & 0.28 & 4 & Fe-LC-2 \\
\hline & 1.02 & 0.09 & 0.22 & 2 & Fe-HS \\
\hline \multirow{6}{*}{$\begin{array}{l}\text { 19. Sovetskoye, aggregates of coalescent } \\
\text { pseudopyramidal grains (II) }\end{array}$} & 0.29 & 0.58 & 0.33 & 14 & $\{6 \mathrm{~S}\}$ \\
\hline & 0.27 & 1.11 & 0.28 & 58 & $\{3 \mathrm{~S} 3 \mathrm{As}\}$ \\
\hline & 0.26 & 1.15 & 0.22 & 8 & $\{2 \mathrm{~S} 4 \mathrm{As}\}$ \\
\hline & 0.29 & 1.58 & 0.22 & 6 & $\{6 \mathrm{As}\}$ \\
\hline & 0.14 & 1.05 & 0.26 & 13 & Fe-LC-1 \\
\hline & 0.97 & 0.20 & 0.22 & 1 & Fe-HS \\
\hline \multirow{4}{*}{$\begin{array}{l}\text { 28. Eldorado, aggregates of coalescent } \\
\text { pseudopyramidal grains (II) }\end{array}$} & 0.28 & 0.61 & 0.33 & 13 & $\{6 S\}$ \\
\hline & 0.25 & 1.12 & 0.34 & 70 & $\{3 \mathrm{~S} 3 \mathrm{As}\}$ \\
\hline & 0.17 & 0.99 & 0.36 & 14 & Fe-LC-1 \\
\hline & 0.92 & 0.12 & 0.24 & 2 & Fe-HS \\
\hline \multirow{5}{*}{$\begin{array}{l}\text { 29. Eldorado, aggregates of coalescent } \\
\text { pseudopyramidal grains (III) }\end{array}$} & 0.27 & 0.62 & 0.37 & 15 & $\{6 \mathrm{~S}\}$ \\
\hline & 0.30 & 1.11 & 0.32 & 66 & $\{3 \mathrm{~S} 3 \mathrm{As}\}$ \\
\hline & 0.12 & 1.06 & 0.28 & 7 & Fe-LC-3 \\
\hline & 0.19 & 1.11 & 0.22 & 8 & Fe-LC-1 \\
\hline & 0.19 & 1.70 & 0.24 & 4 & Fe-LC-2 \\
\hline \multirow{5}{*}{$\begin{array}{l}\text { 30. Eldorado, aggregates of coalescent } \\
\text { pseudopyramidal grains (II) }\end{array}$} & 0.29 & 0.62 & 0.30 & 12 & $\{6 S\}$ \\
\hline & 0.25 & 1.14 & 0.30 & 68 & $\{3 \mathrm{~S} 3 \mathrm{As}\}$ \\
\hline & 0.27 & 1.58 & 0.27 & 6 & $\{6 \mathrm{As}\}$ \\
\hline & 0.18 & 0.78 & 0.34 & 12 & Fe-LC-1 \\
\hline & 0.87 & 0.25 & 0.23 & 2 & Fe-HS \\
\hline \multirow{5}{*}{$\begin{array}{l}\text { 31. Olginskoye, aggregates of coalescent } \\
\text { pseudopyramidal grains (III) }\end{array}$} & 0.28 & 0.58 & 0.32 & 12 & $\{6 S\}$ \\
\hline & 0.25 & 1.08 & 0.33 & 71 & $\{3 \mathrm{~S} 3 \mathrm{As}\}$ \\
\hline & 0.26 & 1.25 & 0.22 & 6 & $\{2 \mathrm{~S} 4 \mathrm{As}\}$ \\
\hline & 0.17 & 1.03 & 0.31 & 8 & Fe-LC-1 \\
\hline & 0.92 & 0.18 & 0.28 & 2 & Fe-HS \\
\hline \multirow{5}{*}{$\begin{array}{l}\text { 32. Olginskoye, aggregates of coalescent } \\
\text { pseudopyramidal grains (III) }\end{array}$} & 0.27 & 0.58 & 0.32 & 12 & $\{6 S\}$ \\
\hline & 0.25 & 1.09 & 0.34 & 70 & $\{3 \mathrm{~S} 3 \mathrm{As}\}$ \\
\hline & 0.28 & 1.27 & 0.25 & 10 & $\{2 \mathrm{~S} 4 \mathrm{As}\}$ \\
\hline & 0.18 & 1.61 & 0.26 & 5 & $\{6 \mathrm{As}\}$ \\
\hline & 0.85 & 0.41 & 0.22 & 2 & Fe-HS \\
\hline \multirow{5}{*}{$\begin{array}{l}\text { 35. Blagodatnoye, disseminated aggregates of } \\
\text { pseudopyramidal grains (III) }\end{array}$} & 0.27 & 0.63 & 0.26 & 8 & $\{6 S\}$ \\
\hline & 0.28 & 1.12 & 0.30 & 54 & $\{3 \mathrm{~S} 3 \mathrm{As}\}$ \\
\hline & 0.26 & 1.56 & 0.27 & 23 & $\{6 \mathrm{As}\}$ \\
\hline & 0.17 & 1.14 & 0.26 & 12 & Fe-LC-1 \\
\hline & 1.03 & 0.07 & 0.23 & 3 & Fe-HS \\
\hline \multirow{7}{*}{$\begin{array}{l}\text { 37. Blagodatnoye, disseminated aggregates of } \\
\text { pseudopyramidal grains (III) }\end{array}$} & 0.29 & 0.64 & 0.33 & 13 & $\{6 S\}$ \\
\hline & 0.28 & 0.96 & 0.25 & 8 & $\{4 \mathrm{~S} 2 \mathrm{As}\}$ \\
\hline & 0.27 & 1.12 & 0.29 & 50 & $\{3 \mathrm{~S} 3 \mathrm{As}\}$ \\
\hline & 0.28 & 1.40 & 0.22 & 8 & $\{2 \mathrm{~S} 4 \mathrm{As}\}$ \\
\hline & 0.26 & 1.67 & 0.28 & 9 & $\{6 \mathrm{As}\}$ \\
\hline & 0.18 & 0.80 & 0.25 & 7 & Fe-LC-1 \\
\hline & 0.17 & 1.33 & 0.26 & 5 & Fe-LC-2 \\
\hline
\end{tabular}


Table 1. Cont.

\begin{tabular}{|c|c|c|c|c|c|}
\hline $\begin{array}{l}\text { Specimen Number, Deposit, Morphology of } \\
\text { Arsenopyrite Grains (Mineralization Stage) }\end{array}$ & $\begin{array}{l}\text { IS, } \mathrm{mm} / \mathrm{s} \\
( \pm 0.005)\end{array}$ & $\begin{array}{c}\mathrm{QS}, \mathrm{mm} / \mathrm{s} \\
( \pm 0.02)\end{array}$ & $\begin{array}{l}\mathrm{W}, \mathrm{mm} / \mathrm{s} \\
( \pm 0.02)\end{array}$ & $\begin{array}{l}A, \% \\
( \pm 3)\end{array}$ & $\begin{array}{c}\text { Configuration } \\
\text { of Ligands }\end{array}$ \\
\hline \multirow{5}{*}{$\begin{array}{l}\text { 40. Gerfed, aggregates of coalescent } \\
\text { pseudopyramidal grains (III) }\end{array}$} & 0.26 & 0.61 & 0.32 & 13 & $\{6 S\}$ \\
\hline & 0.27 & 1.12 & 0.32 & 69 & $\{3 \mathrm{~S} 3 \mathrm{As}\}$ \\
\hline & 0.26 & 1.59 & 0.26 & 8 & $\{6 \mathrm{As}\}$ \\
\hline & 0.14 & 1.07 & 0.22 & 8 & Fe-LC-1 \\
\hline & 0.97 & 0.09 & 0.22 & 2 & Fe-HS \\
\hline \multirow{5}{*}{$\begin{array}{l}\text { 41. Arkhangelskoye, aggregates of coalescent } \\
\text { pseudopyramidal grains (III) }\end{array}$} & 0.29 & 0.56 & 0.33 & 18 & $\{6 S\}$ \\
\hline & 0.27 & 0.97 & 0.33 & 33 & $\{4 \mathrm{~S} 2 \mathrm{As}\}$ \\
\hline & 0.27 & 1.23 & 0.31 & 36 & $\{3 \mathrm{~S} 3 \mathrm{As}\}$ \\
\hline & 0.26 & 1.66 & 0.29 & 7 & $\{6 \mathrm{As}\}$ \\
\hline & 0.10 & 1.08 & 0.21 & 6 & Fe-LC-1 \\
\hline \multirow{4}{*}{$\begin{array}{l}\text { 42. Nikolayevskoye, flattened } \\
\text { pseudopyramidal grains (III) }\end{array}$} & 0.28 & 0.57 & 0.31 & 10 & $\{6 \mathrm{~S}\}$ \\
\hline & 0.27 & 1.12 & 0.32 & 76 & $\{3 \mathrm{~S} 3 \mathrm{As}\}$ \\
\hline & 0.25 & 1.52 & 0.27 & 6 & $\{1 \mathrm{~S} 5 \mathrm{As}\}$ \\
\hline & 0.16 & 1.08 & 0.24 & 8 & Fe-LC-1 \\
\hline \multirow{4}{*}{$\begin{array}{l}\text { 43. Nikolayevskoye, flattened } \\
\text { pseudopyramidal grains (III) }\end{array}$} & 0.27 & 0.65 & 0.34 & 15 & $\{6 S\}$ \\
\hline & 0.24 & 1.11 & 0.28 & 70 & $\{3 \mathrm{~S} 3 \mathrm{As}\}$ \\
\hline & 0.26 & 1.33 & 0.23 & 9 & $\{2 \mathrm{~S} 4 \mathrm{As}\}$ \\
\hline & 0.24 & 1.56 & 0.24 & 6 & $\{6 \mathrm{As}\}$ \\
\hline \multirow{3}{*}{$\begin{array}{l}\text { 44. Veduga, aggregates of coalescent } \\
\text { pseudopyramidal grains (III) }\end{array}$} & 0.26 & 0.66 & 0.34 & 18 & $\{6 \mathrm{~S}]$ \\
\hline & 0.25 & 1.10 & 0.34 & 59 & $\{3 \mathrm{~S} 3 \mathrm{As}\}$ \\
\hline & 0.28 & 1.44 & 0.35 & 22 & $\{2 \mathrm{~S} 4 \mathrm{As}\}$ \\
\hline \multirow{4}{*}{$\begin{array}{l}45 \text { Polyarnaya Zvezda, aggregates of coalescent } \\
\text { pseudopyramidal grains (II) }\end{array}$} & 0.27 & 0.62 & 0.31 & 16 & $\{6 S\}$ \\
\hline & 0.25 & 1.09 & 0.37 & 66 & $\{3 \mathrm{~S} 3 \mathrm{As}\}$ \\
\hline & 0.28 & 1.31 & 0.26 & 11 & $\{2 \mathrm{~S} 4 \mathrm{As}\}$ \\
\hline & 0.28 & 1.57 & 0.24 & 6 & $\{6 \mathrm{As}\}$ \\
\hline \multirow{4}{*}{ 46. Uderey, needle-like grains (III) } & 0.29 & 0.57 & 0.31 & 19 & $\{6 \mathrm{~S}\}$ \\
\hline & 0.25 & 0.98 & 0.31 & 36 & $\{4 \mathrm{~S} 2 \mathrm{As}\}$ \\
\hline & 0.26 & 1.20 & 0.26 & 30 & \{3S3As\} \\
\hline & 0.26 & 1.52 & 0.30 & 15 & $\{1 \mathrm{~S} 5 \mathrm{As}\}$ \\
\hline \multirow{5}{*}{ 47. Uderey, needle-like grains (II) } & 0.29 & 0.54 & 0.28 & 11 & $\{6 S\}$ \\
\hline & 0.26 & 0.95 & 0.36 & 45 & $\{4 \mathrm{~S} 2 \mathrm{As}\}$ \\
\hline & 0.25 & 1.18 & 0.23 & 22 & $\{3 \mathrm{~S} 3 \mathrm{As}\}$ \\
\hline & 0.27 & 1.37 & 0.22 & 14 & $\{2 \mathrm{~S} 4 \mathrm{As}\}$ \\
\hline & 0.25 & 1.64 & 0.32 & 8 & $\{6 \mathrm{As}\}$ \\
\hline \multirow{5}{*}{ 49. Uderey, needle-like grains (V) } & 0.29 & 0.59 & 0.32 & 22 & $\{6 S\}$ \\
\hline & 0.24 & 0.93 & 0.31 & 26 & $\{4 \mathrm{~S} 2 \mathrm{As}\}$ \\
\hline & 0.25 & 1.13 & 0.23 & 22 & $\{3 \mathrm{~S} 3 \mathrm{As}\}$ \\
\hline & 0.26 & 1.33 & 0.29 & 26 & $\{2 \mathrm{~S} 4 \mathrm{As}\}$ \\
\hline & 0.26 & 1.66 & 0.24 & 5 & $\{6 \mathrm{As}\}$ \\
\hline \multirow{5}{*}{ 56. Vasilyevskoye, prismatic grains (III) } & 0.29 & 0.56 & 0.34 & 21 & $\{6 \mathrm{~S}\}$ \\
\hline & 0.25 & 0.90 & 0.30 & 23 & $\{4 \mathrm{~S} 2 \mathrm{As}\}$ \\
\hline & 0.25 & 1.16 & 0.28 & 32 & $\{3 \mathrm{~S} 3 \mathrm{As}\}$ \\
\hline & 0.27 & 1.42 & 0.31 & 20 & $\{2 \mathrm{~S} 4 \mathrm{As}\}$ \\
\hline & 0.22 & 1.71 & 0.38 & 4 & $\{6 \mathrm{As}\}$ \\
\hline \multirow{6}{*}{ 57. Vasilyevskoye, prismatic grains (III) } & 0.29 & 0.50 & 0.34 & 19 & $\{6 S\}$ \\
\hline & 0.28 & 0.79 & 0.24 & 13 & $\{5 \mathrm{~S} 1 \mathrm{As}\}$ \\
\hline & 0.28 & 1.00 & 0.22 & 12 & $\{4 \mathrm{~S} 2 \mathrm{As}\}$ \\
\hline & 0.28 & 1.21 & 0.28 & 34 & $\{3 \mathrm{~S} 3 \mathrm{As}\}$ \\
\hline & 0.26 & 1.57 & 0.31 & 16 & $\{6 \mathrm{As}\}$ \\
\hline & 0.12 & 1.01 & 0.24 & 6 & Fe-LC-1 \\
\hline \multirow{6}{*}{ 58. Vasilyevskoye, prismatic grains (III) } & 0.28 & 0.51 & 0.35 & 18 & $\{6 \mathrm{~S}\}$ \\
\hline & 0.28 & 0.80 & 0.28 & 14 & $\{5 \mathrm{~S} 1 \mathrm{As}\}$ \\
\hline & 0.28 & 0.99 & 0.23 & 14 & $\{4 \mathrm{~S} 2 \mathrm{As}\}$ \\
\hline & 0.28 & 1.21 & 0.29 & 32 & $\{3 \mathrm{~S} 3 \mathrm{As}\}$ \\
\hline & 0.26 & 1.59 & 0.36 & 16 & $\{6 \mathrm{As}\}$ \\
\hline & 0.11 & 1.01 & 0.22 & 6 & Fe-LC-1 \\
\hline \multirow{3}{*}{$\begin{array}{l}\text { 61. Panimba, isometric pseudopyramidal } \\
\text { grains (III) }\end{array}$} & 0.28 & 0.58 & 0.33 & 16 & $\{6 S\}$ \\
\hline & 0.25 & 1.1 & 0.33 & 74 & $\{3 \mathrm{~S} 3 \mathrm{As}\}$ \\
\hline & 0.27 & 1.43 & 0.27 & 10 & $\{2 \mathrm{~S} 4 \mathrm{As}\}$ \\
\hline
\end{tabular}


Table 1. Cont.

\begin{tabular}{|c|c|c|c|c|c|}
\hline $\begin{array}{l}\text { Specimen Number, Deposit, Morphology of } \\
\text { Arsenopyrite Grains (Mineralization Stage) }\end{array}$ & $\begin{array}{c}\text { IS, } \mathrm{mm} / \mathrm{s} \\
( \pm 0.005)\end{array}$ & $\begin{array}{c}\mathrm{QS}, \mathrm{mm} / \mathrm{s} \\
( \pm 0.02)\end{array}$ & $\begin{array}{l}\mathrm{W}, \mathrm{mm} / \mathrm{s} \\
( \pm 0.02)\end{array}$ & $\begin{array}{l}\text { A, \% } \\
( \pm 3)\end{array}$ & $\begin{array}{c}\text { Configuration } \\
\text { of Ligands }\end{array}$ \\
\hline \multirow{4}{*}{$\begin{array}{l}\text { 62. Panimba, isometric pseudopyramidal } \\
\text { grains (III) }\end{array}$} & 0.32 & 0.67 & 0.39 & 21 & $\{6 \mathrm{~S}\}$ \\
\hline & 0.26 & 1.13 & 0.32 & 66 & $\{3 \mathrm{~S} 3 \mathrm{As}\}$ \\
\hline & 0.33 & 1.35 & 0.22 & 5 & $\{2 \mathrm{~S} 4 \mathrm{As}\}$ \\
\hline & 0.06 & 1.08 & 0.28 & 8 & Fe-LC-3 \\
\hline \multirow{3}{*}{$\begin{array}{l}\text { 63. Panimba, isometric pseudopyramidal } \\
\text { grains (II) }\end{array}$} & 0.28 & 0.60 & 0.32 & 14 & $\{6 \mathrm{~S}\}$ \\
\hline & 0.25 & 1.09 & 0.33 & 70 & $\{3 \mathrm{~S} 3 \mathrm{As}\}$ \\
\hline & 0.27 & 1.32 & 0.31 & 16 & $\{2 \mathrm{~S} 4 \mathrm{As}\}$ \\
\hline
\end{tabular}

Notes: IS, $\mathrm{mm} / \mathrm{s}$ is a chemical isomeric shift; $\mathrm{QS}, \mathrm{mm} / \mathrm{s}$ is quadrupole splitting; $\mathrm{W}, \mathrm{mm} / \mathrm{s}$ is the width of absorption line; $\mathrm{A}, \%$ is a fraction of iron population of a particular crystallographic position; I-IV are stages of mineral formation.

The last column in Table 1 provides the identification of ligand surroundings of iron cations on the basis of the monotonic dependence of quadrupole splitting on the number of arsenic atoms in the coordination ligand octahedron (see Figure 3), i.e., reference to a specific configuration of ligands was made on the basis of the values of quadrupole splittings detected in the iron positions spectrum. The determination of configurations is qualitative because the value of quadrupole splitting is influenced specifically by the nature of atom distribution in the following coordination spheres. Table 1 includes the iron positions with an occupation of over $1 \%$ of the total iron content in the specimen.

In some specimens, there are iron positions marked in Table 1 as Fe-HS (high spin), with a high value of the chemical shift $\approx 1 \mathrm{~mm} / \mathrm{s}$ typical for the high-spin state of $\mathrm{Fe}^{2+}$. The occupation of these positions is minor and constitutes $<2 \%$. These positions can be referred to as local areas in the mineral with increased sulfur concentrations. Meanwhile, it is worth noting that the presence of the subspectrum of these positions in the general spectrum of the specimen increases the area of the right line of the doublet. The Goldansky-Karyagin effect can also lead to the doublet asymmetry [42].

The specimens of some deposits contained iron positions marked in the Table 1 as Fe-LC (low-coordinated iron), with a minor chemical shift typical for iron cations with reduced coordination by ligands. It is known that the elementary arsenopyrite cell contains 24 free tetrahedron positions (Figure 4); therefore, it can be assumed that they can be occupied by iron at specific crystal formation conditions. The maximum iron output to tetrahedral positions was detected in arsenopyrites of the Blagodatnoye and Sovetskoye deposit was up to $13 \%$, and the Eldorado was up to $19 \%$ of the total iron content.

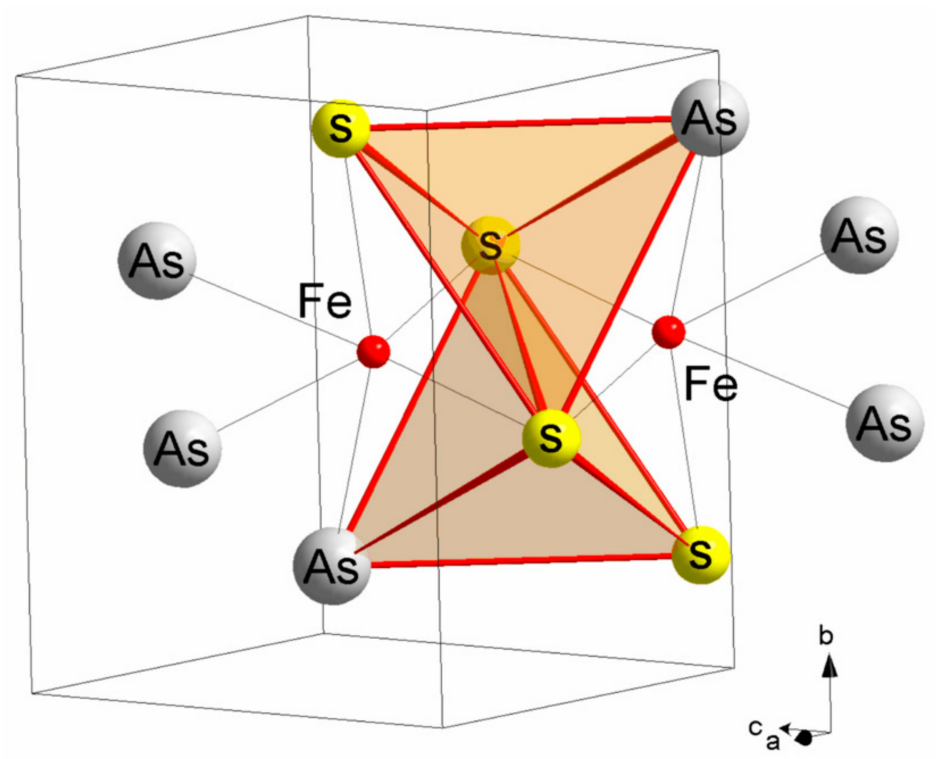

Figure 4. Tetrahedral cavities in the arsenopyrite structure. Thick lines show two of 24 tetrahedral iron positions in the elementary cell of arsenopyrite. 
Therefore, in the studied arsenopyrites, the ligand configurations of the nearest surroundings are formed at almost equal contents of sulfur and arsenic. The maximum occupied configuration is \{3S3As\}. The occurrence of other configurations testifies to the concentration heterogeneity of ligands with variable composition in the specimen and suggests that arsenopyrites are solid solutions of pyrite, arsenopyrite, and loellingite.

Figure 5 shows diagrams of occupation of ligand configurations in arsenopyrite of different deposits, where the preference of the configuration \{3S3As\} in the studied mineral samples is evident. The continuous lines show the distribution of configurations expected upon the chaotic distribution in the crystal of ligands of two structural motives accounting for the span of the S/As ratio in the specimens of this deposit. The evident deviation of the real situation from the statistic distribution of structural motives $\{6 \mathrm{~S}\},\{3 \mathrm{~S} 3 \mathrm{As}\},\{6 \mathrm{As}\}$ in the studied specimens speaks to the fact that the arsenopyrite lattice is thermodynamically more favorable as compared to pyrite or loellingite lattices.

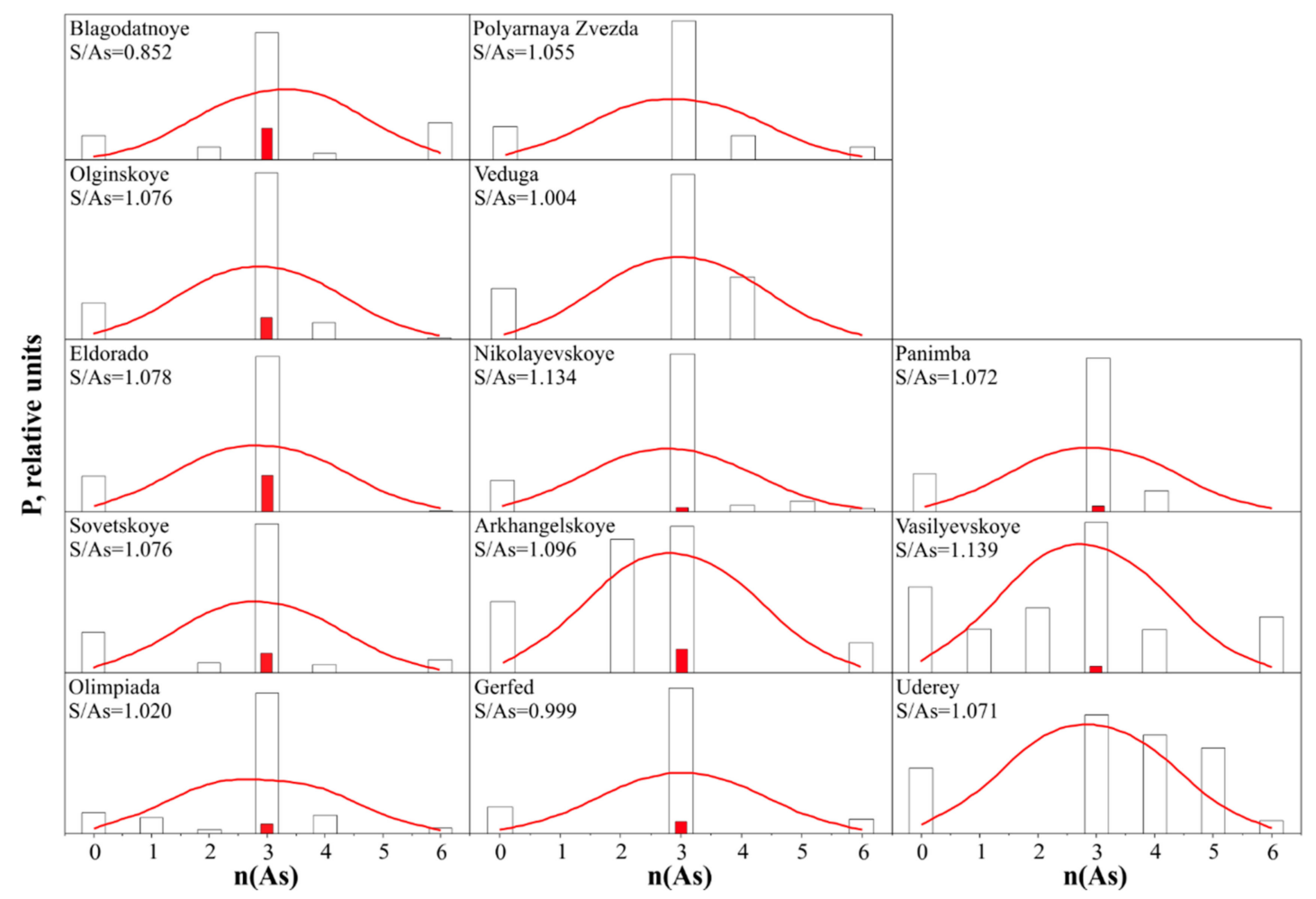

Figure 5. Occupation of ligand configurations in arsenopyrites from different deposits.

Excess of occupation of the ligand configuration $\{6 \mathrm{~S}\}$ over occupation of the $\{6 \mathrm{As}\}$ configuration in arsenopyrite from almost all deposits draws attention. The pyrite "phase" is probably more favorable thermodynamically than the loellingite "phase" for the studied mineral selection. The red column in the background of the configuration \{3S3As\} of the diagrams (Figure 5) shows the population of low-coordinated iron (Fe-LC). The average ratio of the S/As grades is indicated by the numbers of the deposits in brackets. As is seen, there is no strict correlation between the $\mathrm{S} / \mathrm{As}$ ratio and the occupation of ligand configurations. The physicochemical conditions of mineral formation probably significantly influence the set of the implemented ligand configurations of a specific structural motive.

The impact of the geological environment of ore formation on the ligand microstructure of the studied arsenopyrites shall be summarized as follows. The Olimpiada and Panimba deposits located in close proximity to the parent granitoid intrusions $(1.5-2.0 \mathrm{~km})$ and occupying the lower part of the ore shoot have the most ordered arsenopyrites (\{3S3As $\}>70 \%)$. They are characterized by a frequent predominance of arsenic ligands (\{6As\}, \{2S4As\}, \{1S5As\}) over sulfuric ligands (\{6S $\},\{5 \mathrm{~S} 1 \mathrm{As}\},\{4 \mathrm{~S} 2 \mathrm{As}\})$ in the crystal lattice. Arsenopyrites of low structural ordering $(\{3 \mathrm{~S} 3 \mathrm{As}\}=36-22 \%)$ are developed at 
the Vasilievskoye and Uderey deposits, which are the most distant ones from granitoids $(16-18 \mathrm{~km})$ and occupy the upper part of the ore shoot. Sulfuric and arsenic ligands distributed in approximately equal quantities predominate in the crystal lattice of the mineral from these deposits, and there is no Fe in tetrahedral positions (see Table 1). The presence of such regularities may be associated with an inhomogeneous temperature field in the mineral formation environment, contributing to the formation of chemical and structural varieties of the mineral. The reflection of regular variability of the ligand microstructure in arsenopyrite generations has not been revealed in this study, which can probably be explained by the abrupt change in the parameters of formation and recrystallization of the mineral in the ore formation process.

\subsection{Arsenopyrite Composition and Distribution of Impurities of Precious Metals}

Concentrations of the main mineral-forming and impurity elements- $\mathrm{Au}, \mathrm{Ag}, \mathrm{Ru}, \mathrm{Pd}, \mathrm{Pt}$-were determined in arsenopyrite samples (Table 2). The content of mineral-forming elements in arsenopyrite varies within the limits (wt. \%): $\mathrm{Fe}-(32.8-34.7)$; As-(43.3-49.1); S-(17.8-21.9) at the theoretical composition of the mineral Fe-34.3; As-46.0; S-19.7. Arsenopyrites under study are deficient in iron $((\mathrm{S}+\mathrm{As}) / \mathrm{Fe}>2)$, with a variable ratio of $0.85 \leq \mathrm{S} / \mathrm{As} \leq 1.18$ (Table 2). The observed variability in concentrations of the main mineral-forming elements is reflected in the physicochemical conditions of mineral crystallization $[1,5,6,43]$.

The highest concentrations of precious elements are characteristic of gold and silver. The platinoid grade does not exceed $1 \mathrm{ppm}$. The optical and electron microscope study of the samples showed the presence of native gold inclusions of various fineness and aurostibite in arsenopyrite. No $\mathrm{Ag}$, $\mathrm{Ru}, \mathrm{Pd}$, and $\mathrm{Pt}$ minerals were found in arsenopyrite. Gold particles are observed on the surface of arsenopyrite crystals, in fractures, in the form of isometric inclusions, confined to fractures and microdroplet particles outside the cataclasis fractures (Figure 6).

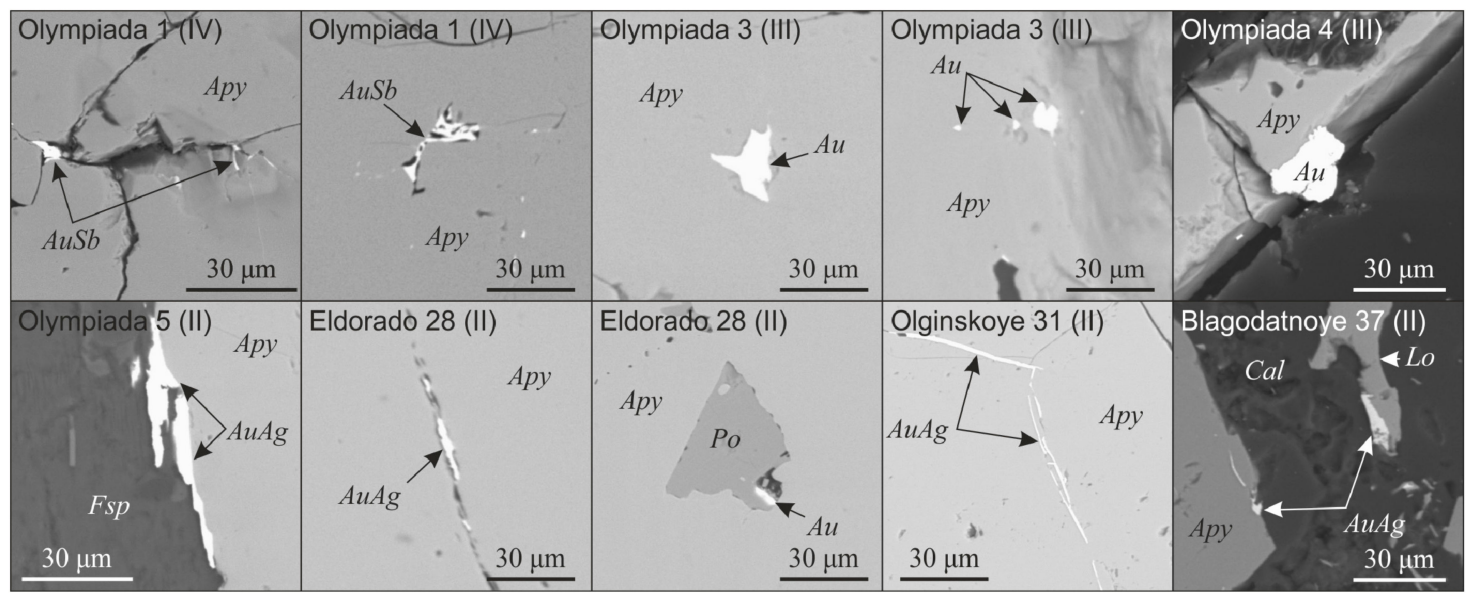

Figure 6. Back-scattered electron (BSE) images of distribution of gold mineral particles in arsenopyrite. Arsenopyrite associations (stages): (II)—sulfide-polymetallic; (III)—ullmannite-gersdorffite; (IV)—stibnite. Abbreviations of minerals: Apy-arsenopyrite; AuSb-aurostibite; Au-native gold (fineness $\geq$ 900\%o); Fsp-alkaline feldspar; AuAg—native gold (fineness 800\%o-899\%o); Po-pyrrhotite; Cal—calcite; Lo-loellingite.

The observed particles of gold minerals were found in samples with minimal concentrations of the element in the samples, and, on the contrary, in some arsenopyrite samples, no gold mineral inclusions were found at high concentrations of gold, according to the ICP tests. Usually, visible gold and aurostibite particles occur in cataclased and recrystallized arsenopyrite grains in association with minerals of the stage of mineral formation following the arsenopyrite stage. The concentration of gold reveals a nonlinear dependence on the composition of the mineral (S/As) (Figure 7). 
Table 2. Composition and parameters of arsenopyrite formation.

\begin{tabular}{|c|c|c|c|c|c|c|c|c|c|c|c|c|c|}
\hline No. & $\mathrm{Fe}$ & As & $S$ & $T^{\circ} \mathrm{C}$ & $\log f S_{2}$ & $\mathrm{Au}$ & $\mathrm{Ag}$ & $\mathbf{R u}$ & $P d$ & $\mathbf{P t}$ & $\Sigma$ & S/As & $(\mathrm{S}+\mathrm{As}) / \mathrm{Fe}$ \\
\hline 1 & 33.9 & 46.4 & 19.7 & 300 & -14.6 & 1.94 & 0.11 & 0.001 & 0.03 & 0.01 & 2.09 & 0.99 & 2.03 \\
\hline 2 & 34.1 & 45.5 & 20.4 & 460 & -5.9 & 0.88 & 3.21 & 0.001 & 0.09 & 0.01 & 4.19 & 1.05 & 2.03 \\
\hline 3 & 33.6 & 47.1 & 19.3 & 340 & -12.8 & 0.36 & 2.18 & 0.001 & 0.07 & 0.00 & 2.61 & 0.96 & 2.05 \\
\hline 5 & 34.1 & 45.4 & 20.5 & 450 & -5.9 & 12.52 & 1.05 & 0.002 & 0.14 & 0.02 & 13.73 & 1.06 & 2.04 \\
\hline 6 & 33.7 & 46.7 & 19.5 & 320 & -13.4 & 4.13 & 6.35 & 0.002 & 0.09 & 0.00 & 10.57 & 0.98 & 2.04 \\
\hline 7 & 33.7 & 46.4 & 19.9 & 300 & -14.6 & 2.22 & 0.55 & 0.001 & 0.09 & 0.02 & 2.87 & 1.00 & 2.05 \\
\hline 18 & 33.9 & 45.5 & 20.6 & 460 & -5.9 & 20.26 & 46.69 & 0.003 & 0.22 & 0.05 & 67.23 & 1.06 & 2.06 \\
\hline 28 & 34.4 & 44.5 & 21.2 & 420 & -6.7 & 3.63 & 14.16 & 0.003 & 0.10 & 0.57 & 18.46 & 1.11 & 2.04 \\
\hline 29 & 34.4 & 44.8 & 20.8 & 440 & -6.4 & 0.32 & 22.98 & 0.003 & 0.10 & 0.49 & 23.90 & 1.09 & 2.02 \\
\hline 30 & 34.2 & 45.6 & 20.2 & 460 & -5.9 & 0.15 & 0.84 & 0.001 & 0.02 & 0.01 & 1.01 & 1.03 & 2.02 \\
\hline 31 & 34.0 & 45.4 & 20.5 & 460 & -5.9 & 1.40 & 3.44 & 0.002 & 0.32 & 0.05 & 5.22 & 1.06 & 2.05 \\
\hline 32 & 34.2 & 44.9 & 21.0 & 440 & -6.4 & 1.56 & 2.72 & 0.001 & 0.15 & 0.03 & 4.46 & 1.09 & 2.05 \\
\hline 35 & 32.8 & 49.1 & 17.8 & 530 & -7.4 & 9.44 & 6.03 & 0.013 & 0.17 & 0.04 & 15.69 & 0.85 & 2.06 \\
\hline 37 & 32.9 & 49.1 & 18.0 & 510 & -7.5 & 38.45 & 63.66 & 0.001 & 0.06 & 0.65 & 102.82 & 0.86 & 2.06 \\
\hline 40 & 33.9 & 46.2 & 19.8 & 300 & -14.6 & 6.14 & 49.92 & 0.002 & 0.16 & 0.73 & 56.96 & 1.00 & 2.03 \\
\hline 41 & 34.3 & 44.7 & 21.0 & 430 & -6.5 & 40.56 & 15.27 & 0.001 & 0.07 & 0.12 & 56.02 & 1.10 & 2.04 \\
\hline 43 & 34.3 & 44.2 & 21.4 & 415 & -6.8 & 10.90 & 25.81 & 0.003 & 0.11 & 0.00 & 36.83 & 1.13 & 2.05 \\
\hline 44 & 33.8 & 46.2 & 19.8 & 300 & -14.6 & 5.40 & 23.52 & 0.002 & 0.03 & 0.00 & 28.96 & 1.00 & 2.04 \\
\hline 45 & 34.2 & 45.3 & 20.4 & 455 & -6.0 & 29.70 & 26.00 & 0.003 & 0.08 & 0.00 & 55.79 & 1.05 & 2.03 \\
\hline 46 & 34.3 & 45.2 & 20.5 & 450 & -6.2 & 36.18 & 18.54 & 0.002 & 0.26 & 0.02 & 55.00 & 1.06 & 2.02 \\
\hline 47 & 34.4 & 45.0 & 20.7 & 445 & -6.4 & 87.41 & 378.71 & 0.001 & 0.09 & 0.02 & 466.22 & 1.07 & 2.02 \\
\hline 49 & 34.3 & 44.9 & 20.7 & 445 & -6.4 & 34.11 & 21.61 & 0.000 & 0.27 & 0.02 & 56.02 & 1.08 & 2.03 \\
\hline 56 & 34.2 & 44.6 & 21.1 & 430 & -6.5 & 24.46 & 10.20 & 0.002 & 0.15 & 0.02 & 34.84 & 1.10 & 2.04 \\
\hline 57 & 34.7 & 43.3 & 21.9 & 390 & -7.4 & 89.13 & 3.64 & 0.001 & 0.05 & 0.01 & 92.83 & 1.18 & 2.03 \\
\hline 58 & 34.5 & 44.2 & 21.4 & 415 & -6.8 & 63.78 & 9.66 & 0.002 & 0.02 & 0.00 & 73.46 & 1.13 & 2.03 \\
\hline 61 & 34.4 & 45.0 & 20.5 & 445 & -6.4 & 4.92 & 18.08 & 0.004 & 0.14 & 0.04 & 23.19 & 1.07 & 2.01 \\
\hline 62 & 34.2 & 44.9 & 20.8 & 445 & -6.4 & 3.61 & 11.49 & 0.003 & 0.23 & 0.04 & 15.38 & 1.08 & 2.04 \\
\hline 63 & 34.1 & 45.2 & 20.6 & 450 & -6.1 & 2.40 & 10.59 & 0.002 & 0.39 & 0.04 & 13.42 & 1.07 & 2.04 \\
\hline
\end{tabular}

Notes: The first column contains the laboratory number corresponding to the laboratory number in Table 1 ; Columns $2-4$ present the grades of elements, the average value in the sample,
in wt. \% Columns $5-6$ contain $T{ }^{\circ} \mathrm{C}$ and $\log f \mathrm{~S}_{2}$ determined by [1,43]; Columns 7-12 present concentrations of precious metals and their total grade, in ppm; Columns 13 and 14 provide the indicator ratios of $\mathrm{S}, \mathrm{As}$, and $\mathrm{Fe}$, calculated on the basis of atomic quantities. 


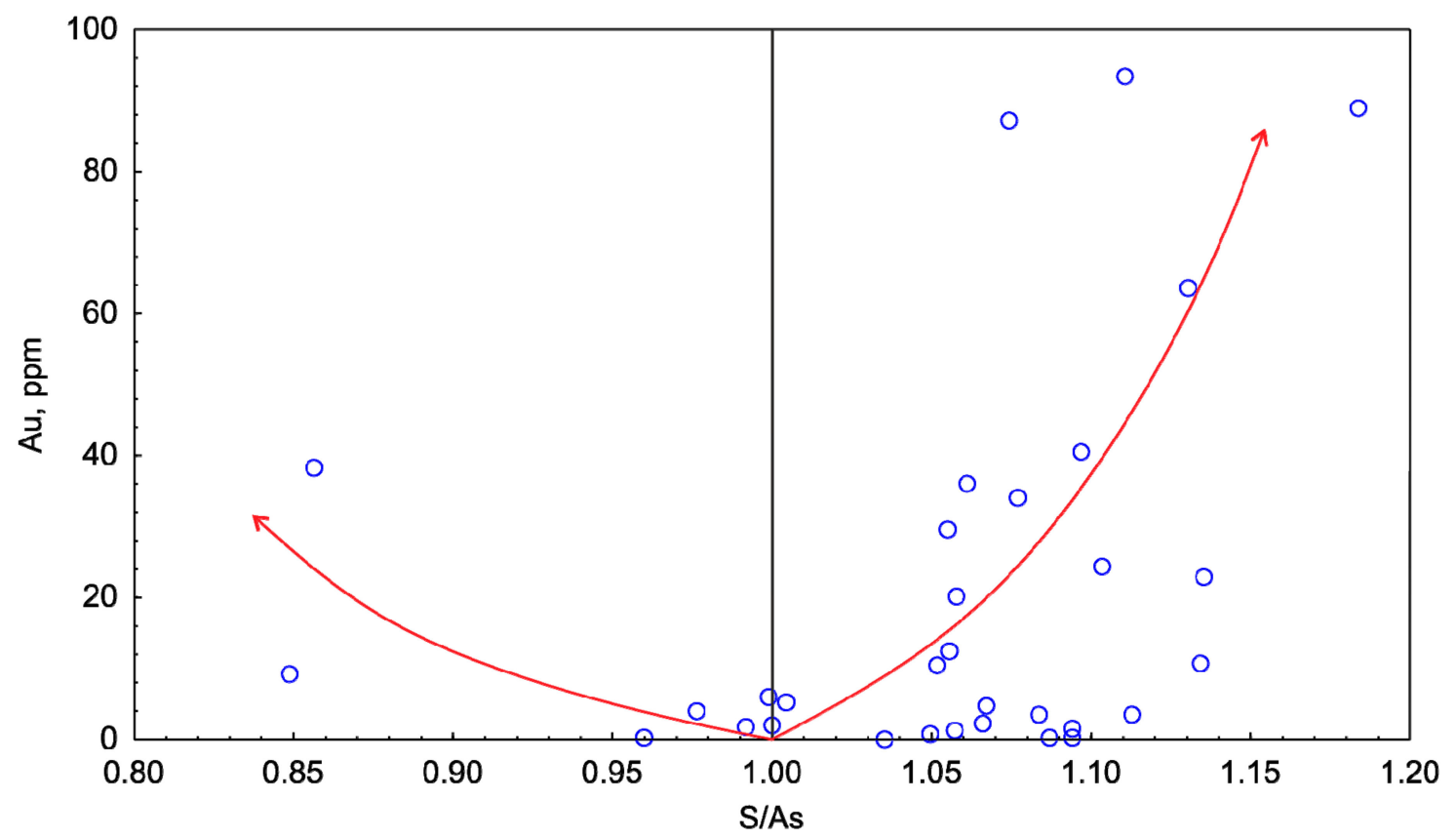

Figure 7. Distribution of gold in arsenopyrite depending on S/As ratio.

The revealed tendency of correlation between gold, sulfur, and arsenic concentrations suggests the presence of gold in arsenopyrite in the form of isomorphic impurity or solid solution. Thermodynamic calculations [44] confirm this assumption, since the fields of existence of complex gold with sulfur and arsenic ions in solutions coincide with the fields of pyrite and arsenopyrite stability. In this case, it is assumed that there are atoms of gold introduction in the mineral structure along with the observed crypto-inclusions of native gold.

Crystallization of arsenopyrite of the studied samples took place in the range of $300-520^{\circ} \mathrm{C}$ and sulfur activity $\log f S_{2}=-5.8--14.6$ [32]. Increased concentrations of precious metals were revealed in nonstoichiometric mineral varieties formed at temperatures 385-410, 430, 445-450, and $510{ }^{\circ} \mathrm{C}$ and sulfur activity $\log f S_{2}=-7.4-7.0,-6.5,-6.3--6.1$ and -8.0 , respectively. The previous work on studying the stability of minerals of the Fe-As-S system, as well as the behavior of gold and silver in hydrothermal solutions, indicate that the formation of various parageneses and stability of $\mathrm{Au}$ and Ag complexes depend on many factors-partial pressure of sulfur and arsenic, acidity-alkalinity and redox potential of the medium, temperature, and pressure [44-55].

Gold concentrations ( $<1 \mathrm{wt}$. \%) are not recorded in the Mössbauer spectra. In the studied arsenopyrite samples, the gold content does not exceed $0.01 \mathrm{wt}$. \%, which does not allow the Mössbauer spectra to confirm the possibility of the element entering the crystal lattice in the form of isomorphic impurity or introduction atoms. A collection of a series of arsenopyrite samples with discrete values of the content of "invisible" gold over $1 \mathrm{wt}$. \% is required to determine the forms of gold and the nature of the bond in the crystal lattice. The conclusion made earlier by Genkin et al. [9,17] on the presence of chemically bound gold in arsenopyrite suggests it is located in the coordination octahedra instead of iron. High symmetry of gold allowed Genkin [9] to refer the observed singlet characterizing high local symmetry to gold. Only the octahedron has high symmetry among tetrahedral and octahedral structural chains in arsenopyrite, but the explanation of the charge state of gold and its covalent bond with $\mathrm{S}$ and As remains to be determined conclusively. Moreover, the study of gold forms in arsenopyrite with the Mössbauer spectroscopy method should be carried out on the ${ }^{197} \mathrm{Au}$ nuclei more diligently than in the paper [17]. Without the knowledge of the charge state of gold and the nature of covalent effects, it is impossible to draw conclusions about the method of chemical binding of gold in arsenopyrite. The results of the study of the mineral ligand microstructure show regularities, which indicate that the increased gold grades in arsenopyrite are typical upon the reduction of its 
structural stoichiometry and are accompanied by the occurrence of the configurations $\{5 \mathrm{~S} 1 \mathrm{As}\},\{4 \mathrm{~S} 2 \mathrm{As}\}$, \{1S5As\}. The tendency of the gold grade to increase upon the reduction of the share of the \{3S3As\} configurations and iron in the low-coordinated condition (Fe-LC) was also identified.

Trigub et al. [56,57] demonstrated the possibility of replacing iron atoms in the structure of arsenopyrite and pyrite with gold atoms using synthetic minerals of the Fe-As-S system. However, in our case, there is no correlation between the iron and gold grades, which may indicate a different mechanism of gold entry into the mineral structure. On the other hand, the same paper [56,57] demonstrates the extraction of isomorphic gold in pyrite into metallic, nanoscale gold, upon thermal metamorphism of the mineral. Recently, we [58,59] found gold enrichment of pyrite varieties with an increase and decrease of the $\mathrm{S} / \mathrm{Fe}$ ratio from the stoichiometric one- $\mathrm{S} / \mathrm{Fe}=2$. D. Fougerouse et al. [60] showed the possibility of remobilization and redeposition of gold from arsenopyrite under the influence of late fluids. It is possible that some of the gold in the arsenopyrite samples we have determined was redeposited due to thermal metamorphism or late fluid impact, and hides the existing correlations. In this case, the occurrence of the later pyrite-pyrrhotite-chalcopyrite-sphalerite-galena mineral association in the ores has a significant impact on the morphological features of gold particles, with their usual significant increase in sizes (Figure 8). Observations indicate a late generation of visible gold, and early gold, which is in association with early arsenopyrite, pyrrhotite, and pyrite, is an invisible form representing isomorphic gold, or a group of atoms of introduction [6,59,61,62]. Arsenopyrite in association with $\mathrm{Cu}, \mathrm{Pb}$, and $\mathrm{Zn}$ sulfide minerals is characterized by the poikiloblastic structure (Figure 8a), with numerous inclusions of galena among non-ore minerals. Native gold forms continuous edges around arsenopyrite. Gold inclusions in pyrite are sometimes geometrically ordered, reminiscent of the structure of decay or helicite structure, which occurs in the form of linear (in the polished section) distribution of gold particles in the host mineral (see Figure 8c). The spine-like-grained gold aggregate in cataclased vein quartz (see Figure $8 \mathrm{~d}$ ) is spatially distant from the sulfide aggregates and occupies the intergranular space in vein quartz and thin wedge-shaped cataclasis fractures, characterizing the final stage of gold deposition [6,62].
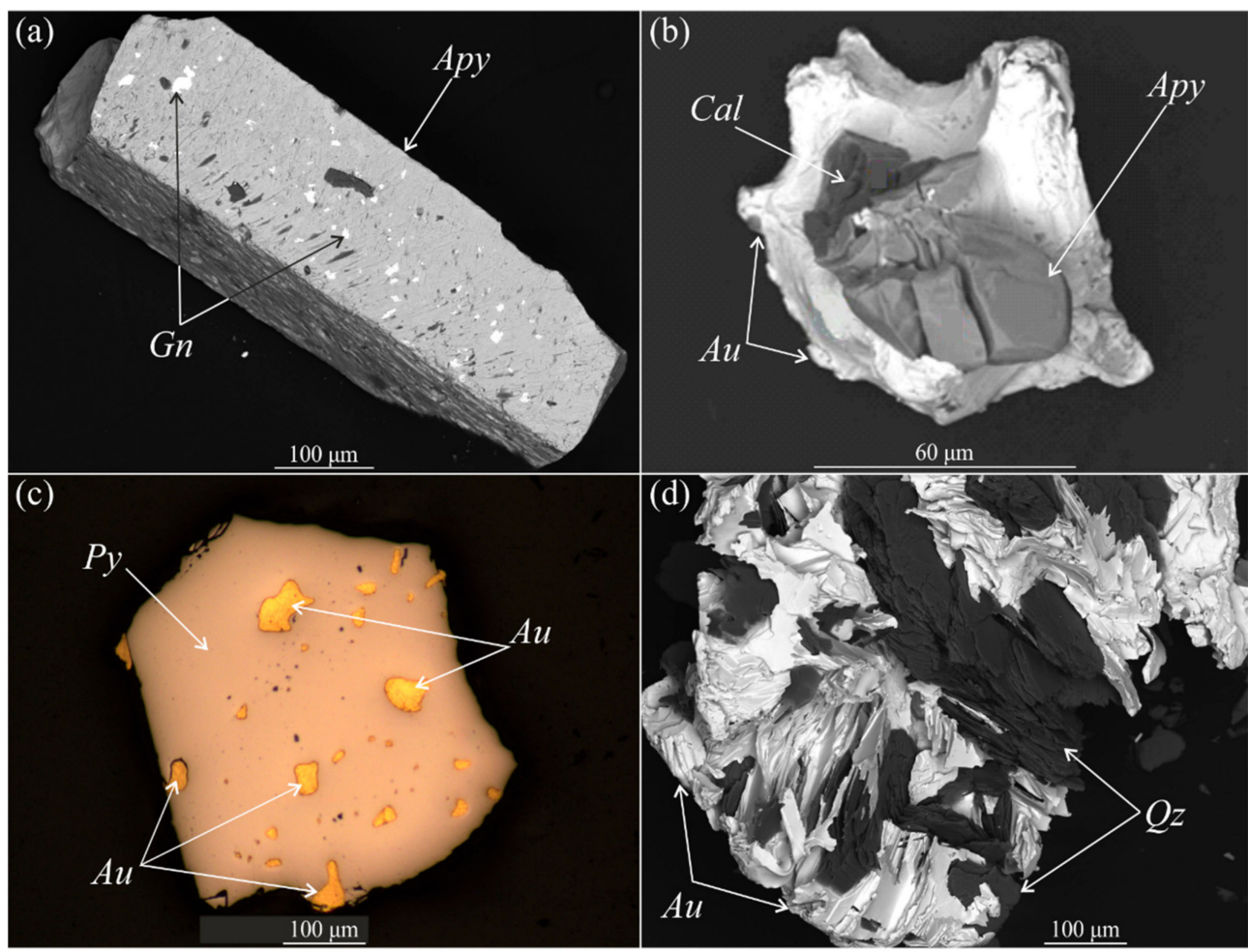

Figure 8. BSE $(\mathrm{a}, \mathrm{b}, \mathrm{d})$ and optical (c) photo of structural and textural features of associations of the sulfide-polymetallic ore-formation stage: (a) arsenopyrite (Apy) poikiloblast with galena (Gn) inclusions; 
(b) margin of native gold $(\mathrm{Au})$ growth around arsenopyrite with calcite (Cal) inclusion; (c) strip distribution of native gold $(\mathrm{Au})$ inclusions in pyrite (Py) crystalloblast; (d) morphology of intergranular-fractured native gold $(\mathrm{Au})$ aggregate in cataclased quartz $(\mathrm{Qz})$.

\section{Conclusions}

The Mössbauer studies of arsenopyrite specimens from gold ore deposits of the Yenisei Ridge were carried out. In the mineral, the ligand configurations of the coordination octahedron around the iron cation, differing from the configuration \{3S3As\} typical for the stoichiometric arsenopyrite FeAsS, were detected. The occupation of configurations with other compositions of the ligand surroundings is not subordinated to the statistic distribution. Natural arsenopyrites can be considered a solid pyrite, loellingite, and arsenopyrite solution with the physicochemical preference to the formation in the arsenopyrite-pyrite-loellingite order.

Iron output to tetrahedral positions was detected in arsenopyrites of some deposits. It is assumed that the nature of ligand disordering and the occupation of tetrahedral iron positions are preconditioned by the features of thermodynamic and geological conditions of mineral formation.

The composition of arsenopyrite is characterized by variability in the concentrations of main and impurity elements in different parts of grains, neighboring grains of disseminated aggregates, and in the ores of different deposits. The elevated gold and other precious elements' concentrations are typical for the mineral, with the predominance of sulfur or arsenic in relation to the stoichiometric composition $(0.85 \leq \mathrm{S} / \mathrm{As} \leq 1.18)$, reduced structural stoichiometry for ligand configurations $\{5 \mathrm{~S} 1 \mathrm{As}\},\{4 \mathrm{~S} 2 \mathrm{As}\}$, \{1S5As\} and reduction of the share of the configurations \{3S3As\} and iron in the low-coordinated condition (Fe-LC). The structure of arsenopyrite assumes that gold atoms have been incorporated.

Author Contributions: Conceptualization, A.M.S. and S.A.S.; Data curation, S.A.S., O.A.B. and Y.V.K.; Investigation, A.M.S., S.A.S., O.A.B., Y.V.K., Y.A.Z., and P.A.T.; Writing-Original draft, A.M.S., S.A.S., O.A.B., Y.V.K., Y.A.Z., and P.A.T.

Funding: The work was supported by the Russian Foundation for Basic Research (project number 19-35-90017) and the Government of the Russian Federation (project 14.Y26.31.0012).

Acknowledgments: We thank Ye.V. Korbovyak for X-ray energy dispersive microanalysis; Ye.V. Rabtsevich and Ye.I. Nikitin for ICP-MS study. We are grateful to G.A. Palyanova, three anonymous reviewers, and the Editorial Board members, for their comments and improvements.

Conflicts of Interest: The authors declare no conflicts of interest.

\section{References}

1. Kretschmar, U.; Scott, S.D. Phase relations involving arsenopyrite in the system Fe-As-S and their application. Can. Mineral. 1976, 14, 364-386.

2. Sharp, Z.D.; Essene, E.J.; Kelly, W.C. A reexamination of the arsenopyrite geothermometer: Pressure considerations and applications to natural assemblages. Can. Mineral. 1985, 23, 517-534.

3. Sustavov, S.G.; Murzin, V.V.; Ivanov, O.K.; Litoshko, D.N. Arsenopyrite. In Ural Mineralogy: Arsenides and stibnides. Tellurides. Selenides. Fluorides. Chlorides and Bromides; Ural Branch of the Russian Academy of Sciences: Sverdlovsk, Russia, 1991; pp. 4-12. (In Russian)

4. Murzin, V.V.; Semenkin, V.A.; Pikulev, A.I.; Mil'der, O.B.; Sustavov, S.G.; Krinov, D.I. Mössbauer spectroscopic evidence for nonequivalent sites of iron atoms in gold-bearing arsenopyrite. Geochem. Int. 2003, 41, 812-820.

5. Tyukova Ye, E.; Voroshin, S.V. Composition and Parageneses of Arsenopyrite in Deposits and Hosting Rocks of the Upper Kolyma Region (for Interpretation of Sulfide Associations Genesis); SVKNII of the Far-Eastern Branch of the Russian Academy of Sciences: Moscow, Russia, 2007; p. 107. (In Russian)

6. Sazonov, A.M.; Kirik, S.D.; Silyanov, S.A.; Bayukov, O.A.; Tushin, P.A. Typomorphism of arsenopyrite from Blagodatnoye and Olimpiada gold ore deposits (Yenisei Ridge). Mineralogy 2016, 3, 52-70. (In Russian)

7. Stankovič, J.; Jančula, D. K typochemizmu arzenopyritu z niektorých ložísk na južných svahoch Nízkych Tatier. Miner. Slovaca 1981, 13, 373-377. 
8. Boiron, M.C.; Cathelineau, M.; Trescases, J.J. Conditions of gold-bearing arsenopyrite crystallization in the Villeranges Basin, Marche-Combrailles shear zone, France: A mineralogical and fluid inclusion study. Econ. Geol. 1989, 84, 1340-1362. [CrossRef]

9. Genkin, A.D. Gold-bearing arsenopyrite from gold ore deposits: Internal structure of grains, composition, growth mechanism and state of gold. Geol. ore Depos. 1998, 40, 551-557. (In Russian)

10. Kovalev, K.R.; Kalinin, Y.A.; Naumov, Y.A.; Kolesnikova, M.K.; Korolyuk, V.N. Gold-bearing arsenopyrite in eastern Kazakhstan gold-sulfide deposits. Russ. Geol. Geophys. 2011, 52, 178-192. [CrossRef]

11. Fuess, H.; Kratz, T.; Töpel-Schadt, J.; Miehe, G. Crystal structure refinement and electron microscopy of arsenopyrite. Z. Krist. 1987, 179, 335-346. [CrossRef]

12. Wagner, F.E.; Marion, P.; Regnard, J.-R. ${ }^{197}$ Au Mössbauer study of gold ores, mattes, roaster products, and gold minerals. Hyperfine Interact. 1988, 41, 851-854. [CrossRef]

13. Johan, Z.; Marcoux, E.; Bonnemaison, M. Arsenopyrite aurifere: Mode de substitution de Au dans la structure de FeAsS. Comptes Rendus Acad. Sci. 1989, 308, 185-191.

14. Friedl, J.; Wagner, F.E.; Sawicki, J.A.; Harris, D.C.; Mandarino, J.A.; Marion, P. ${ }^{197} \mathrm{Au},{ }^{57} \mathrm{Fe}$ and ${ }^{121} \mathrm{Sb}$ Mössbauer study of gold minerals and ores. Hyperfine Interact. 1992, 70, 945-948. [CrossRef]

15. Mumin, A.H.; Fleet, M.E.; Chryssoulis, S.L. Gold mineralization in As-rich mesothermal gold ores of the Bogosu-Prestea mining district of the Ashanti Gold Belt, Ghana: Remobilization of "invisible" gold. Miner. Depos. 1994, 29, 445-460. [CrossRef]

16. Jiuling, L.; Daming, F.; Jeng, Q.; Guilan, Z. The existence of the negative valence state of gold in sulfide minerals and its formation mechanism. Acta Geol. Sin. 1995, 69, 67-77.

17. Genkin, A.D.; Bortnikov, N.S.; Cabri, L.J.; Wagner, F.E.; Stanley, C.J.; Safonov, Y.G.; McMahon, G.; Friedl, J.; Kerzin, A.L.; Gamyanin, G.N. A multidisciplinary study of invisible gold in arsenopyrite from four mesothermal gold deposits in Siberia, Russian Federation. Econ. Geol. 1998, 93, 463-487. [CrossRef]

18. Cabri, L.J.; Newville, M.; Gordon, R.A.; Crozier, E.D.; Sutton, S.R.; McMahon, G.; Jiang, D.-T. Chemical speciation of gold in arsenopyrite. Can. Mineral. 2000, 38, 1265-1281. [CrossRef]

19. Sung, Y.-H.; Brugger, J.; Ciobanu, C.L.; Pring, A.; Skinner, W.; Nugus, M. Invisible gold in arsenian pyrite and arsenopyrite from a multistage Archaean gold deposit: Sunrise Dam, Eastern Goldfields Province, Western Australia. Miner. Depos. 2009, 44, 765-775. [CrossRef]

20. Zhu, Y.; Fang, A.; Tan, J. Geochemistry of hydrothermal gold deposits: A review. Geosci. Front. 2011, 2, 367-374. [CrossRef]

21. Silva, J.C.M.; De Abreu, H.A.; Duarte, H.A. Electronic and structural properties of bulk arsenopyrite and its cleavage surfaces-A DFT study. RSC Adv. 2015, 5, 2013-2023. [CrossRef]

22. Kravtsova, R.G.; Tauson, V.L.; Nikitenko, E.M. Modes of Au, Pt, and Pd occurrence in arsenopyrite from the Natalkinskoe deposit, NE Russia. Geochem. Int. 2015, 53, 964-972. [CrossRef]

23. Buerger, M.J. The symmetry and crystal structure of the minerals of the arsenopyrite group. Z. Krist. 1936, 95, 83-113. [CrossRef]

24. Morimoto, N.; Clark, L.A. Arsenopyrite crystal-chemical relations. Am. Mineral. 1961, 46, 1448-1469.

25. Kirik, S.D.; Sazonov, A.M.; Silyanov, S.A.; Bayukov, O.A. Investigation of disordering in natural arsenopyrite by X-ray powder crystal structure analysis and nuclear gamma resonance. J. Sib. Fed. Univ. Eng. Technol. Ser. 2017, 10, 578-592. (In Russian) [CrossRef]

26. Nickel, E.H. Structural stability of minerals with the pyrite, marcasite, arsenopyrite and loellingite structures. Can. Mineral. 1968, 9, 311-323.

27. Bindi, L.; Moëlo, Y.; Léone, P.; Suchaud, M. Stoichiometric arsenopyrite, FeAsS, from La Roche-Balue Quarry Loire-Atlantique, France: Crystal structure and Mössbauer study. Can. Mineral. 2012, 50, 471-479. [CrossRef]

28. Kerler, W.; Neuwirth, W.; Fluck, E.Z. Isomerieverschiebung und Quadrupolaufspaltung beim Mößbauer-Effekt von $\mathrm{Fe}^{57}$ in Eisenverbindungen. Z. Phys. 1963, 175, 200-220. [CrossRef]

29. Evans, B.J.; Johnson, R.G.; Senftle, F.E.; Blaine Cecil, C.; Dulong, F. The ${ }^{57}$ Fe Mössbauer parameters of pyrite and marcasite with different provenances. Geochim. Cosmochim. Acta 1982, 46, 761-775. [CrossRef]

30. Imbert, P.; Gerard, A.; Wintenberger, M. Study of naturally occurring sulfides, sulfarsenides, and arsenides of iron by Mössbauer effect. Comptes Rendus 1963, 256, 4391-4393.

31. Kjekshus, A.; Nicholson, D.G. The significance of $\pi$ Back-Bonding in compounds with pyrite, marcasite and arsenopyrite Type structures. Acta Chem. Scand. 1971, 25, 866-876. [CrossRef] 
32. Sazonov, A.M.; Zvyagina Ye, A.; Silyanov, S.A.; Lobanov, K.V.; Leontyev, S.I.; Kalinin Yu, A.; Savichev, A.A.; Tishin, P.A. Ore genesis of the Olimpiada gold deposit (Yenisei Ridge, Russia). Geosph. Res. 2019, 17-43. (In Russian) [CrossRef]

33. Sazonov, A.M.; Bernatonis, V.K. Features of formation of gold-bearing quartz-vein zones in crystalline slates. In Geological and Geochemical Criteria of Gold Mineralization; Nauka: Novosibirsk, Russia, 1990; pp. 44-57. (In Russian)

34. Sazonov, A.M.; Ananiev, A.A.; Vlasov, V.S. On the conditions of spatial combination of gold ore and antimony mineralization in slate strata of one of the Siberian regions. In Geological and Geochemical Criteria of Gold Mineralization; Nauka: Novosibirsk, Russia, 1990; pp. 84-96. (In Russian)

35. Sazonov, A.M.; Sarayev, V.A.; Ananiev, A.A. Sulfide and quartz gold deposits in metamorphic strata of the Yenisei Ridge. Geol. Geophys. 1991, 5, 28-37. (In Russian)

36. Sazonov, A.M.; Zvyagina, E.A.; Romanovsky, A.E.; Shvedov, G.I.; Leontiev, S.I. Aposlate gold-bearing metasomatites of beresite formation (Yenisei Ridge). Geol. Geophys. 1995, 36, 53-61. (In Russian)

37. Sazonov, A.M.; Ananyev, A.A.; Poleva, T.V.; Khokhlov, A.N.; Vlasov, V.S.; Zvyagina, E.A.; Fedorova, A.V.; Tishin, P.A.; Leontyev, S.I. Gold metallogeny of the Yenisei Ridge: Geological and structural position, structural types of ore fields. J. Sib. Fed. Univ. Ser. Eng. Technol. 2010, 3, 371-395. (In Russian)

38. Gibsher, N.A.; Sazonov, A.M.; Travin, A.V.; Tomilenko, A.A.; Ponomarchuk, A.V.; Sil'yanov, S.A.; Nekrasova, N.A.; Shaparenko, E.O.; Ryabukha, M.A.; Khomenko, M.O. Age and duration of the formation of the Olimpiadinski gold deposit (Yenisei ridge, Russia). Geochem. Int. 2019, 57, 593-599. [CrossRef]

39. Sazonov, A.M. Geochemistry of Gold in Metamorphic Strata; Publishing House of TPU: Tomsk, Russia, 1998; p. 168. (In Russian)

40. Brostigen, G.; Kjekshus, A. Redetermined Crystal Structure of FeS 2 (Pyrite). Acta Chem. Scand. 1969, 23, 2186-2188. [CrossRef]

41. Lutz, H.D.; Jung, M.; Waschenbach, G. Kristallstrukturen des lollingits FeAs 2 und des pyrits RuTe 2 . Z. Anorg. Allg. Chem. 1987, 554, 87-91. [CrossRef]

42. Goldansky, V.I. Chemical Applications of Moessbauer Spectroscopy; Mir: Moscow, Russia, 1970; p. 504. (In Russian)

43. Scott, S.D. Chemical behaviour of sphalerite and arsenopyrite in hydrothermal and metamorphic environments. Mineral. Mag. 1983, 47, 427-435. [CrossRef]

44. Pavlov, A.L.; Pavlova, L.K. Elements of thermodynamics of gold behavior in ore formation sample. In Physics and Physicochemistry of Ore-Forming Processes; Nauka: Novosibirsk, Russia, 1971; pp. 121-147. (In Russian)

45. Kolonin, G.R.; Palyanova, G.A.; Shironosova, G.P. Stability and solubility of arsenopyrite in hydrothermal solutions. Geochemistry 1988, 6, 843-855. (In Russian)

46. Palyanova, G.A.; Kolonin, G.R. Arsenopyrite-containing mineral associations as indicators of physical and chemical conditions of hydrothermal ore formation. Geochemistry 1991, 10, 1481-1492. (In Russian)

47. Reich, M.; Kesler, S.; Utsunomiya, S.; Palenik, C.S.; Chryssoulis, S.L.; Ewing, R.C. Solubility of gold in arsenian pyrite. Geochim. Cosmochim. Acta 2005, 69, 2781-2796. [CrossRef]

48. Pokrovski, G.S.; Roux, J.; Ferlat, G.; Jonchiere, R.; Seitsonen, A.P.; Vuilleumier, R.; Hazemann, J.-L. Silver in geological fluids from in situ X-ray absorption spectroscopy and first-principles molecular dynamics. Geochim. Cosmochim. Acta 2013, 106, 501-523. [CrossRef]

49. Pokrovski, G.S.; Tagirov, B.R.; Schott, J.; Hazemann, J.-L.; Proux, O. A new view on gold speciation in sulfurbearing hydrothermal fluids from in situ X-ray absorption spectroscopy and quantum-chemical modeling. Geochim. Cosmochim. Acta 2009, 73, 5406-5427. [CrossRef]

50. Pokrovski, G.S.; Tagirov, B.R.; Schott, J.; Bazarkina, E.F.; Hazemann, J.-L.; Proux, O. An in situ X-ray absorption spectroscopy study of gold-chloride complexing in hydrothermal fluids. Chem. Geol. 2009, 259, 17-29. [CrossRef]

51. Mikhlin, Y.; Likhatski, M.; Tomashevich, Y.; Romanchenko, A.; Erenburg, S.; Trubina, S. XAS and XPS examination of the $\mathrm{Au}-\mathrm{S}$ nanostructures produced via the reduction of aqueous gold(III) by sulfide ions. J. Electron Spectrosc. Relat. Phenom. 2010, 177, 24-29. [CrossRef]

52. Pokrovski, G.S.; Kara, S.; Roux, J. Stability and solubility of arsenopyrite, FeAsS, in crustal fluids. Geochim. Cosmochim. Acta 2002, 66, 2361-2378. [CrossRef]

53. Morey, A.A.; Tomkins, A.G.; Bierlein, F.P.; Weinberg, R.F.; Davidson, G.J. Bimodal Distribution of Gold in Pyrite and Arsenopyrite: Examples from the Archean Boorara and Bardoc Shear Systems, Yilgarn Craton, Western Australia. Econ. Geol. 2008, 103, 599-614. [CrossRef] 
54. Xing, Y.; Brugger, J.; Tomkins, A.; Shvarov, Y. Arsenic evolution as a tool for understanding formation of pyritic gold ores. Geology 2019, 47, 335-338. [CrossRef]

55. Vilor, N.V.; Pavlova, L.A.; Kaz'min, L.A. Aresenopyrite-pyrite paragenesis in gold deposits (thermodynamic modeling). Russ. Geol. Geophys. 2014, 55, 824-841. [CrossRef]

56. Trigub, A.L.; Tagirov, B.R.; Kvashnina, K.O.; Lafuerza, S.; Filimonova, O.N.; Nickolsky, M.S. Experimental determination of gold speciation in sulfide-rich hydrothermal fluids under a wide range of redox conditions. Chem. Geol. 2017, 471, 52-64. [CrossRef]

57. Trigub, A.L.; Tagirov, B.R.; Kvashnina, K.O.; Chareev, D.A.; Nickolsky, M.S.; Shiryaev, A.A.; Baranova, N.N.; Kovalchuk, E.V.; Mokhov, A.V. X-ray spectroscopy study of the chemical state of "invisible" Au in synthetic minerals in the Fe-As-S system. Am. Mineral. 2017, 102, 1057-1065. [CrossRef]

58. Sazonov, A.M.; Ananyev, A.A.; Ananyeva, T.A.; Leontiev, S.I. Reflection of gold-bearing content of low-sulphide quartz veins in typomorphism of constituent minerals. ZVMO 1991, 2, 17-24. (In Russian)

59. Sazonov, A.M.; Zvyagina, E.A.; Krivoputskaya, L.M. Structural and chemical heterogeneity of pyrite of Sarala deposit (Kuznetsky Alatau). Geol. Geophys. 1992, 8, 87-95. (In Russian)

60. Fougerouse, D.; Micklethwaite, S.; Tomkins, A.G.; Mei, Y.; Kilburn, M.; Guagliardo, P.; Fisher, L.A.; Halfpenny, A.; Gee, M.; Paterson, D.; et al. Gold remobilisation and formation of high grade ore shoots driven by dissolution-reprecipitation replacement and $\mathrm{Ni}$ substitution into auriferous arsenopyrite. Geochim. Cosmochim. Acta 2016, 178, 143-159. [CrossRef]

61. Sazonov, A.M.; Onufrienok, V.V.; Kolmakov, Y.V.; Nekrasova, N.A. Pyrrhotite of gold-bearing ores: Composition, spot defects, magnetic properties, gold distribution. J. Sib. Fed. Univ. Eng. Technol. 2014, 7, 717-737. (In Russian)

62. Palyanova, G.A.; Sazonov, A.M.; Zhuravkova, T.V.; Silyanov, S.A. Composition of pyrrhotite as an indicator of mineralization conditions at the Sovetskoye gold deposit. Russ. Geol. Geophys. 2019, 60, 735-751. [CrossRef]

(C) 2019 by the authors. Licensee MDPI, Basel, Switzerland. This article is an open access article distributed under the terms and conditions of the Creative Commons Attribution (CC BY) license (http://creativecommons.org/licenses/by/4.0/). 